\title{
The Antitumor Mechanism of the Polyphenol- enriched Ethyl Acetate Fraction Extract of Glechoma hederacea (Lamiaceae) against HepG2 Cells Involves Apoptosis Pathways
}

\author{
Wen-Wan Chao \\ Kainan University \\ Yu-Jhen Liou \\ Providence University \\ Hao-Ting Ma \\ Providence University \\ Yi-Hua Chen \\ Providence University \\ Su-Tze Chou ( $\nabla$ stchou@pu.edu.tw) \\ Providence University https://orcid.org/0000-0002-6588-0358
}

\section{Research}

Keywords: apoptosis, Glechoma hederacea (Lamiaceae), HepG2 cells, ROS, polyphenols

Posted Date: December 2nd, 2020

DOI: https://doi.org/10.21203/rs.3.rs-117496/v1

License: (a) (1) This work is licensed under a Creative Commons Attribution 4.0 International License.

Read Full License 
1 The Antitumor Mechanism of the Polyphenol-enriched Ethyl Acetate

2 Fraction Extract of Glechoma hederacea (Lamiaceae) against HepG2

3 Cells Involves Apoptosis Pathways

4

5 Wen-Wan Chao ${ }^{1}$, Yu-Jhen Liou ${ }^{2,3}$, Hao-Ting $\mathrm{Ma}^{2}$, Yi-Hua Chen ${ }^{2}$, Su-Tze $\mathrm{Chou}^{2 *}$

6

$7 \quad{ }^{1}$ Department of Nutrition and Health Sciences, Kainan University, Taoyuan, 33857, Taiwan

$8 \quad{ }^{2}$ Department of Food and Nutrition, Providence University, Taichung, 433, Taiwan

$9 \quad{ }^{3}$ Department of nutrition, show chwan memorial hospital, Taiwan

10

$13 *$ Corresponding author:

14 Su-Tze Chou

15 Department of Food and Nutrition, Providence University, 200, Sec. 7, Taiwan

16 Boulevard, Shalu Dist., Taichung, 43301, Taiwan, R. O. C.

$17 \quad$ Tel.: +886-4-26328001 ext. 15327

18 Fax: $+886-4-26328001$

19 E-mail: stchou@ pu.edu.tw

20 


\section{Abstract}

2 Background: Glechoma hederacea (Lamiaceae) is a traditional Chinese herb

3 belonging to the Labiatae family and has many biological activities. This study aimed

4 to investigate the in vitro effects of different polar parts of the water extracts of $G$.

5 hederacea (Lamiaceae) on HepG2 cells and the possible underlying mechanism.

6 Methods: The cytotoxic effects were determined using the MTT assay. Apoptosis

7 was quantified using annexin V-FITC/PI staining. Caspase-3 and caspase-9 activities

8 were measured using PhiphiLux- $\mathrm{G}_{1} \mathrm{D}_{2}$ kit. Apoptosis-related protein expression was

9 determined using western blot analysis. Reactive oxygen species (ROS) generation, mitochondrial transmembrane potential (MMP), and calcium ion levels were measured using specific fluorescence probes and flow cytometry. The HepG2 cell antioxidant state was determined using DAPI and comet assay, and antioxidant enzyme activities. The polyphenol contents of different polar parts of fractional extracts were determined using HPLC.

Results: Our results showed that rosmarinic acid, caffeic acid, and ferulic acid were the major polyphenolic components in the ethyl acetate fraction extract (EAFE) of $G$. hederacea L.. EAFE could significantly inhibit HepG2 cell proliferation, induce apoptosis, and cause S phase arrest. The apoptogenic activity of EAFE involved ROS induction, $\mathrm{Ca}^{2+}$ accumulation, glutathione depletion, MMP disruption, caspases 3, 9 activation, and $\mathrm{Bax} / \mathrm{Bcl}-2$ ratio increment.

21 Conclusion: Our findings suggest that the polyphenols in the EAFE can inhibit HepG2 cell growth and induce apoptosis through the mitochondria-mediated pathway and ROS-mediated endoplasmic reticulum stress. EAFE could be developed as a

24 functional food or nutraceutical ingredient for chemotherapy.

25 Keywords: apoptosis, Glechoma hederacea (Lamiaceae), HepG2 cells, ROS, polyphenols 


\section{Background}

2 Hepatocellular carcinoma is the fifth most common cancer type and the third leading

3 cause of cancer-related deaths worldwide, accounting for $75 \%$ to $85 \%$ of all primary

4 liver cancer cases. The major cause of carcinogenesis such as hepatocarcinogenesis is

5 a complex process that involves cell injury, inflammation, proliferation, and genomic

6 instability, leading to alterations in several oncogenic pathways [1]. The HepG2 cell

7 line was derived from the liver hepatocellular carcinoma of a Caucasian male. HepG2

8 cells retain many biological characteristics of primary hepatocytes, and protein

9 degradation is important for cellular processes such as cell cycle, antigen processing, apoptosis, and lipid metabolism in the liver [2, 3].

11 Reactive oxygen species (ROS) generation plays a central role in the regulation of both extrinsic and intrinsic apoptosis induction in cancer cells. ROS activate the intrinsic or mitochondrial apoptosis pathway by inducing mitochondrial pore formation, resulting in cytochrome c release into the cytosol [4]. Low and moderate levels of ROS promote cancer cell proliferation and survival through post-translational modification of multiple cellular proteins and kinases. The overproduction of ROS may result in mitochondrial dysfunction, including mitochondrial membrane potential (MMP, $\Delta \Psi \mathrm{m}$ ) loss and mitochondrial apoptosis pathway activation. MMP is critical for maintaining the biological function of cells, and the decrease in MMP may trigger the activation of the intrinsic apoptosis pathway (for example, cytochrome c, Apaf-1, and caspase-9) [5]. The perturbation of mitochondria appears to trigger the initiation of the apoptotic cascade, where the loss of MMP facilitates the release of apoptotic factors [such as cytochrome $\mathrm{c}$ and apoptosis-inducing factor (AIF)] from the mitochondrial intermembrane space into the cytoplasm. This induces the propagation of the apoptotic cascade and the execution of cell death $[6,7]$. 
1 Natural plant compounds are bioactive elements isolated from natural plants.

2 Potential plant-derived compounds act as inhibitors in several stages of tumorigenesis

3 and inflammatory and fibrosis processes. Bioactivity-guided fractionation of active

4 plant extracts can further improve the activity and isolation of the compounds

5 responsible for anticancer activity. Many complementary and alternative therapies,

6 either chemopreventive or chemotherapeutic, are largely inspired by nature,

7 particularly phytochemicals. Several studies have shown that natural plant compounds

8 elicit antiaging, anticancer, and other health-enhancing effects [8-10]. Herbal

9 medicine derived from plant extracts constitutes an indispensable part of traditional medicine and is being increasingly utilized to treat numerous clinical diseases. Cancer cells are often resistant to anticancer drugs because of their capacity to resist drug-induced apoptosis. Various studies have shown that many plant extracts and plant-derived compounds induce cancer cell death through apoptosis without producing significant adverse effects [11, 12].

Glechoma hederacea L. is a traditional Chinese herbal medicine belonging to the Labiatae family. G. hederacea L., commonly known as ground ivy, is a perennial 17 hairy herb with a creeping stem. It is widely distributed across Asia, Europe, and 18 America. It has been previously reported that $G$. hederacea var. longituba shows an inhibitory effect on IFN- $\gamma /$ LPS-induced NO in a dose-dependent manner, on the pro-inflammatory cytokine, IL-12p70, and on TNF- $\alpha$ production in stimulated mouse peritoneal macrophages [13]. We previously showed that the hot water extracts of $G$. hederacea L. (HWG) possess antioxidant activity owing to the presence of polyphenolic compounds [14]. Supporting evidence indicated that G. hederacea L. 24 extracts possess various biological activities, including depigmentation, 25 antimelanogenic, antitumor, antioxidative, hepatoprotective, and anti-inflammatory 26 [14-18]. This study aimed to investigate the effects of different polar parts of $G$. 
1 hederacea L. extracts on the proliferation and apoptosis of HepG2 cells in vitro; our

2 findings might provide a basis for further study on the antihepatocarcinoma effect of 3 the HWG.

\section{$5 \quad$ Materials and methods}

\section{Chemicals and reagents}

7 DMEM (Gibco/BRL), fetal bovine serum, penicillin, streptomycin, and trypsin-EDTA

8 were obtained from Invitrogen. Ethyl acetate; $n$-butanol; gallic acid; catechin;

9 chlorogenic acid; caffeic acid; daidzin; ferulic acid; rutin; genistin; rosmarinic acid; quercetin; genistein; flavone; 3-(4,5-dimethylthiazol-2-yl)-2,5-diphenylterazolium bromide salt (MTT); 4,6-diamino-2-phenylindole (DAPI); propidium iodide; agarose; glutathione (GSH); $\alpha$-thiobarbituric acid; dimethyl sulfoxide; and isopropanol were purchased from Sigma Chemical (St. Louis, MO). In addition $2^{\prime}, 7^{\prime}$-dichlorofluorescein diacetate and 3,3'-dihexyloxacarbocyanine iodide were obtained from Invitrogen. Primary antibodies against Bcl-2, Bax, AIF, Endo G, and cytochrome c were purchased from Cell Signaling, Chemicon, and Santa Technology, Inc.

Preparation of $G$. hederacea $L$. extract and subfraction extracts

22 Naturally grown G. hederacea L. were obtained from Taichung City, Taiwan. A 23 voucher specimen was identified by Dr Bing-Shiunn Chen and deposited at the 24 Department of Horticulture, National Chung Hsing University, Taichung City, 25 Taiwan (No., NCHU-2016-001). G. hederacea L. extracts were prepared in accordance with our previously reported procedures [14]. In brief, whole $G$. 
1 hederacea L. plants were cut into small pieces and extracted at 1:50 (w/v) dilutions in 2 distilled water $\left(100{ }^{\circ} \mathrm{C}\right.$ for $\left.3 \mathrm{~h} ; \mathrm{HWG}\right)$.

3 The subfractions of HWG were obtained via layered extraction by using various

4 solvents such as ethyl acetate, $n$-butanol, and water. Ethyl acetate fraction extract 5 (EAFE), $n$-butanol fraction extract (NBFE), and water fraction extract (WFE) were 6 obtained. Individual extracts were filtered, lyophilized, and stored at $-70{ }^{\circ} \mathrm{C}$ until use.

\section{Cell cultures}

9 Hepatocellular carcinoma cell line HepG2 cells were purchased from Bioresource Collection and Research Center (Hsinchu, Taiwan) and maintained in DMEM containing 10\% fetal bovine serum, 100 units $/ \mathrm{mL}$ penicillin, and $100 \mathrm{mg} / \mathrm{mL}$ streptomycin in a humidified atmosphere with $5 \% \mathrm{CO}_{2}$ at $37{ }^{\circ} \mathrm{C}$.

\section{Determination of cell viability}

HepG2 cells were plated onto a $6 \mathrm{~cm}$ dish at a density of $1 \times 10^{5}$ cells $/ \mathrm{mL} /$ well. The cells were treated with 50,100, 200, and $400 \mu \mathrm{g} / \mathrm{mL}$ of HWG, EAFE, NBFE, and WFE alone and incubated at $37{ }^{\circ} \mathrm{C}$ for $24 \mathrm{~h}$. After incubation, cell viability was determined in accordance with our previously described method [14].

\section{Determination of cell cycle}

21 HepG2 cells were plated onto 12 -well plates at a density of $8 \times 10^{4}$ cells $/ \mathrm{mL} / \mathrm{well}$.

22 The cells treated with $350 \mu \mathrm{g} / \mathrm{mL}$ of EAFE for $12-48 \mathrm{~h}$. Cells were washed with PBS,

23 fixed in $70 \%$ cold ethanol, resuspended in a buffer containing $0.05 \mathrm{mg} / \mathrm{mL}$ propidium

24 iodide for cell cycle and apoptosis analysis by using a Cytoflex flow cytometer (2 25 Laser FACS Calibur; Becton-Dickinson Biosciences). 


\section{DAPI and comet assay}

2 HepG2 cells were plated onto a $10 \mathrm{~cm}$ dish at a density of $1.2 \times 10^{5}$ cells $/ \mathrm{mL} / \mathrm{well}$.

3 The cells were treated with $350 \mu \mathrm{g} / \mathrm{mL}$ of EAFE for $12-48 \mathrm{~h}$. DAPI staining was

4 conducted to detect apoptotic changes in HepG2 cells caused by HWG. DNA damage

5 in HepG2 cells was detected using the comet assay, which involved the use of the

$6 \quad$ single-cell gel electrophoresis method described by Chao et al [14].

8 Detection of ROS, $\mathrm{Ca}^{2+}$ production levels, and MMP $(\Delta \Psi \mathrm{m})$

9 HepG2 cells $\left(8 \times 10^{4}\right.$ cells $\left./ \mathrm{mL}\right)$ were plated onto 12 -well plates and treated with 350 $10 \mu \mathrm{g} / \mathrm{mL}$ of EAFE for various times $(1,3,6,12,24$, and $48 \mathrm{~h})$. Cells were harvested; 11 washed twice; re-suspended in $500 \mu \mathrm{L}$ of 2,7-dichlorodihydrofluorescein diacetate (10 $12 \mu \mathrm{M}$; dye for staining of ROS), Indo-1-AM (3 $\mu \mathrm{g} / \mathrm{mL}$; fluorescent dye for $\left.\mathrm{Ca}^{2+}\right)$, and 3,3'-dihexyloxacarbocyanine iodide (4 $\mu \mathrm{mol} / \mathrm{L}$; fluorescent dye for MMP); and incubated at $37{ }^{\circ} \mathrm{C}$ for 30 min to detect changes in ROS, $\mathrm{Ca}^{2+}$, and MMP levels by using flow cytometry, as described previously [19].

\section{Caspase- 3 and caspase- 9 activity}

HepG2 cells at a density of $8 \times 10^{4}$ cells/well were plated onto 12 -well plates and grown for $24 \mathrm{~h}$. The cells were then treated with $350 \mu \mathrm{g} / \mathrm{mL}$ of EAFE or dimethyl sulfoxide (solvent control) and grown at $37^{\circ} \mathrm{C}$ in a humidified environment with $5 \%$ $\mathrm{CO}_{2}$ for 12,24 , and $48 \mathrm{~h}$. Cells from each well were harvested, and $50 \mu \mathrm{L}$ of $10 \mu \mathrm{M}$ substrate solution (PhiphiLux- $\mathrm{G}_{1} \mathrm{D}_{2}$ kit includes a unique class of substrates for caspase-3 and caspase-9) was then added to the cell pellets. Cells were then incubated at $37{ }^{\circ} \mathrm{C}$ for 60 min and washed once with $1 \mathrm{~mL}$ of ice-cold PBS and resuspended in fresh 1 mL PBS. Caspase-3 and caspase-9 activity was analyzed using flow cytometry 
2 Western blot analyses

3 Total proteins were extracted from cells, and their concentrations were determined

4 using a bicinchoninic acid protein assay kit (Pierce). The samples were separated

5 using SDS-PAGE and then transferred to polyvinylidene fluoride membranes. The

6 blots were incubated overnight at $4{ }^{\circ} \mathrm{C}$ with primary antibodies, including Bcl-2, Bax,

7 AIF, Endo $G$ and cytochrome c, and $\beta$-actin, and then incubated for $1 \mathrm{~h}$ with the

8 secondary antibody. Band intensities were measured using Image $\mathrm{J}$ software.

9

Measurement of lipid peroxide (malondialdehyde); reduced GSH levels; and glutathione peroxidase, superoxide dismutase, and catalase activities HepG2 cells were plated onto a $10 \mathrm{~cm}$ dish at a density of $1.2 \times 10^{5}$ cells $/ \mathrm{mL} / \mathrm{well}$.

13 Cells were incubated with $350 \mu \mathrm{g} / \mathrm{mL}$ of EAFE for various times (12, 24, and $48 \mathrm{~h}$ ).

14 Cells were harvested and then sonicated with phosphate buffer ( $\mathrm{pH}$ 6.8) containing 1 $15 \mathrm{mM}$ PMSF to obtain cell homogenates. The malondialdehyde (MDA), GSH, 16 glutathione peroxidase (GPx), superoxide dismutase SOD, and catalase (CAT) were 17 determined in accordance with our previously reported procedures [14].

\section{HPLC analysis}

20 The polyphenolic compounds in G. hederacea L. extracts were determined by 21 performing HPLC analysis in accordance with our previously described method, with 22 modifications [20]. According to the plot of the peak-area ratio (y) vs concentration 23 (x), the regression equations of the constituents and their correlation coefficients $\mathbb{B}$ 24 were quantified using external standards for which the standard curves had an $\mathrm{r}^{2}$ value 25 of $\geq 0.9999$. 


\section{Statistical analysis}

All assays were conducted a minimum of three times with three different sample preparations. All data are expressed as mean \pm SD. Analysis of variance (ANOVA) was performed using SPSS software (version 16.0; SPSS Inc., USA). One-way ANOVA and Scheffe's method were used to determine the differences between the means, with differences of $p<0.05$ considered statistically significant.

\section{Results}

\section{Effects of HWG and subfraction extracts on HepG2 cell viability}

Effects of the crude extract and the three solvent fractions of $\mathrm{HWG}$ on the proliferation of HepG2 cells were determined using the MTT assay. HepG2 cells were treated with varying concentrations $(50-400 \mu \mathrm{g} / \mathrm{mL})$ of different partition layers, i.e., EAFE, NBFE, and WFE, for $24 \mathrm{~h}$ (Fig. 1). The results indicated that HWG, EAFE, and WFE decreased the percentage of viable cells in a concentration-dependent manner. Among them, EAFE was the most effective. Thus, we measured the selective anticancer activity of the partition layer EAFE for further studies.

\section{EAFE induced S-phase arrest and apoptosis in HepG2 cells}

The cytotoxicity results are shown in Fig. 2A. EAFE dose-dependently inhibited the proliferation in HepG2 cells. The 50\% inhibitory concentration $\left(\mathrm{IC}_{50}\right)$ of EAFE was $350 \mu \mathrm{g} / \mathrm{mL}$ (Fig. 2A).

Cell cycle phase G0/G1 is the cells at the resting phase, $\mathrm{S}$ is the synthesis phase where DNA replication starts, and G2/M is where cells prepare to enter mitotic division. Cancer cells show uncontrolled proliferation and have the potential to resist apoptotic death, both of which are beneficial for cancer progression. Therefore, the inhibition of cell cycle progression and activation of apoptotic pathways are valuable 
1 therapeutic targets [21]. To determine the effect of EAFE on cell cycle arrest in

2 HepG2 cells, we investigated the cell cycle distribution by using flow cytometry. The

3 results revealed that EAFE significantly disrupted cell cycle progression and induced

4 cell cycle arrest at $\mathrm{S}$ phase in HepG2 cells in a time-dependent manner (Fig. 2B).

5 Analysis of the phase of apoptosis that was mainly induced by EAFE revealed that the

6 number of cells in late apoptosis had mainly increased (Fig. 2C).

8 EAFE induced apoptosis and DNA damage in HepG2 cells: Analysis using DAPI staining and comet assay

DAPI staining was conducted to detect any apoptotic changes induced by EAFE in HepG2 cells. Comet assay (single cell gel electrophoresis), which detects breaks in the single- and double-stranded naked supercoiled DNA, was used to evaluate the DNA damage induced by chemical oxidants.

EAFE induced apoptosis, as was revealed by the light staining of nuclei with DAPI, indicating an increase in apoptotic cells (Fig. 3A). EAFE-induced DNA damage was noted by the extension of the comet tail in EAFE-treated cells (Fig. 3B). The images showed that most of the DNA migrated out of the nuclei, indicating that EAFE caused severe damage to the nuclear scaffold. The treatments induced different grades of DNA damage, as indicated by the presence of DNA in the tail. DNA damage response may lead to cell death through apoptosis. The effects on DAPI staining and comet assay were time-dependent. These findings suggest that EAFE markedly induced DNA damage in HepG2 cells.

EAFE affects the production of $\mathrm{ROS}$ and $\mathrm{Ca}^{2+}$ and decreases MMP $(\Delta \psi \mathrm{m})$ in HepG2 cells

The DCFH-DA probe was used to measure the level of ROS in HepG2 cells after 
treatment with EAFE. Fluo-3 AM fluorescent probes were used to detect the levels of

$2 \mathrm{Ca}^{2+}$. The endoplasmic reticulum is the main storage site for intracellular $\mathrm{Ca}^{2+}$. During

3 stress, $\mathrm{Ca}^{2+}$ is released from the endoplasmic reticulum. Mitochondria, which can

4 regulate the frequency of oscillatory $\mathrm{Ca}^{2+}$ signals and blunt the spread of cytosolic

$5 \mathrm{Ca}^{2+}$ waves, acted as a firewall that control the $\mathrm{Ca}^{2+}$ concentration in the cells and in

6 cytoplasmic microdomains on the mitochondria-mediated death pathway [22].

7 HepG2 cells treated with $350 \mu \mathrm{g} / \mathrm{mL}$ of EAFE for $1-48 \mathrm{~h}$ were harvested for ROS,

$8 \mathrm{Ca}^{2+}$, and MMP determinations. EAFE promoted ROS and $\mathrm{Ca}^{2+}$ production as well as 9 decreased the levels of MMP in HepG2 cells; these effects were time-dependent (Fig. $10 \quad 4 \mathrm{~A}-4 \mathrm{C})$.

EAFE induces caspase-3 and caspase-9 activity in HepG2 cells

13 Caspase-3 and caspase-9 are key proteins in the mitochondrial apoptosis pathway [23]. HepG2 cells treated with $350 \mu \mathrm{g} / \mathrm{mL}$ of EAFE for 12,24 , and $48 \mathrm{~h}$ were harvested for caspase-3 and caspase-9 activity determination. EAFE increased the staining of cells, as revealed using the PhiPhilux kit. EAFE promoted caspase-3 and caspase-9 activity in HepG2 cells in a time-dependent manner (Fig. 5A and 5B).

EAFE induces HepG2 cell apoptosis and regulates the levels of apoptosis-related proteins

21 MMP is mainly regulated by the interaction between members of the Bcl-2 family, and the ratio of Bax to $\mathrm{Bcl}-2$ is considered an important upstream checkpoint for the mitochondrial pathway. HepG2 cells treated with $350 \mu \mathrm{g} / \mathrm{mL}$ of EAFE for 12, 24, and $48 \mathrm{~h}$ were harvested. We then examined the levels of apoptosis-associated molecules in HepG2 cells by using western blotting. The data revealed that the protein levels of 
1 whereas that of Bcl-2 significantly decreased in EAFE-treated HepG2 cells compared

2 to those in the control group (Fig. 6A and B). EAFE promoted the release of AIF,

3 Endo G, and cytochrome c from the mitochondria in a time-dependent manner (Fig.

4 6). Taken together, the above data suggest that EAFE probably induces HepG2 cell

5 apoptosis through caspase-dependent and caspase-independent mitochondrial

6 pathways. Our results suggest that EAFE is an effective apoptosis-inducing agent for

7 HepG2 cells, which causes S-phase arrest and ER stress as well as induces

8 mitochondria-mediated apoptotic pathways.

9

Effect of EAFE on MDA production, GSH levels, and antioxidant enzyme activities in HepG2 cells

Oxidative stress can be attributed to an increase in free radical production and/or a decrease in antioxidant defense. ROS generation plays a central role in the regulation of both extrinsic and intrinsic apoptosis induction in cancer cells. HepG2 cells treated with $350 \mu \mathrm{g} / \mathrm{mL}$ of EAFE for 12,24 and $48 \mathrm{~h}$ showed increased MDA levels $(0.54 \pm$ $0.02,0.70 \pm 0.01,0.77 \pm 0.01$, and $0.81 \pm 0.01 \mathrm{mmol} \mathrm{mg} /$ protein; Fig. 7A). MDA is the final product of lipid peroxidation, and its content can indirectly reflect the degree of oxidative stress. Conversely, our results indicated that GSH levels were reduced in EAFE-treated HepG2 cells (Fig. 7B). For further evaluation of the antioxidant activity of EAFE, we determined the activity of important cellular antioxidant enzymes. The activity of the investigated antioxidant enzymes (GSH-Px, SOD, and CAT) was found to increase in EAFE-treated HepG2 cells (Fig. 7C-7E).

\section{HPLC analysis of the polyphenol contents of EAFE, NBFE, and WFE}

For most traditional Chinese medicines, the active ingredient may be a mixture of certain ingredients. Phytochemicals have attracted attention as source materials for the 
1 development of new drugs or alternative therapies for the management of diseases.

2 The HPLC chromatogram of the three active partitioned fractional extracts from

3 HWG exhibited a total of 12 peaks, which were identified by comparing the retention

4 times with those of standard reference compounds (Fig. 8A-8D): 1, gallic acid (4.83

$5 \mathrm{~min}) ; 2$, catechin (13.3 $\mathrm{min}) ; \mathbf{3}$, chlorogenic acid (13.97 min); 4, caffeic acid (15.90

$6 \mathrm{~min}) ; \mathbf{5}$, daidzin $(21.29 \mathrm{~min}) ; \mathbf{6}$, ferulic acid $(24.11 \mathrm{~min}) ; \mathbf{7}$, rutin $(26.00 \mathrm{~min}) ; \mathbf{8}$,

7 genistin (27.95 $\mathrm{min})$; 9, rosmarinic acid (32.92 $\mathrm{min}) ; \mathbf{1 0}$, quercetin (40.71 $\mathrm{min})$; 11,

8 genistein (46.87 $\mathrm{min}$ ); and 12, flavone (55.12 $\mathrm{min})$. The HPLC chromatogram showed

9 that rosmarinic acid (RA), caffeic acid (CA), and ferulic acid (FA) were the major

10 components among the organic molecules found in partitioned fractional extracts. The

11 polyphenolic profiles were considerably more abundant in the EAFE fraction.

12 The concentrations of phenolic compounds in EAFE, NBFE, and WFE are shown

13 in Table 1. The three major compounds identified were RA, CA, and FA. The highest 14 polyphenol content in EAFE was rosmarinic acid $(17410.42 \pm 580.45 \mathrm{mg} / 100 \mathrm{~g})$ and 15 caffeic acid $(6107.04 \pm 160.16 \mathrm{mg} / 100 \mathrm{~g})$.

17 Discussion

18 Intracellular sources of ROS are distributed in various organelles, including the 19 mitochondria, endoplasmic reticulum, and peroxisomes. Excess generation of ROS upon stimuli leads to oxidative stress and oxidative DNA damage, resulting in the loss of MMP, which ultimately determines the cell fate toward apoptotic cell death by activating certain pathways [24]. ROS are one of the major inducers of DNA damage and $\Delta \Psi \mathrm{m}$ dissipation. Cancer cells require relatively high ROS levels for their existence; thus, cellular ROS levels are maintained at higher levels in cancer cells. 
1 higher ROS levels undergo cell death $[6,7,25]$. There are two common mechanisms

2 identified in drug-induced inhibition of cancer cell proliferation. First,

3 chemotherapeutic drugs induce cell cycle arrest, especially in the S or G2/M phase,

4 with consequent inhibition of cell growth. Second, such drugs trigger the apoptotic

5 pathway in cells. In fact, the S-phase of the cell cycle is associated with cell apoptosis

$6 \quad[25]$.

7 Oxidative stress is considered to be important for the promotion of apoptosis in

8 response to various apoptotic stimuli. ROS play an essential role in the oxidative

9 stress response. Mitochondria are involved in several events leading to apoptosis,

10 such as generation of ROS, loss of $\Delta \Psi \mathrm{m}$, release of apoptotic factors, and regulation

11 of Bcl-2 family proteins. Excess ROS results in potentially cytotoxic "oxidative

12 stress." Activation of the mitochondria-mediated intrinsic apoptotic pathway is also a

13 key mechanism involved in the function of antitumor drugs.

14 Mitochondria play a critical role in the regulation of various apoptotic processes, 15 including drug-induced apoptosis. Bcl-2 family members such as the pro-apoptotic 16 protein $\mathrm{Bax}$ and anti-apoptotic protein $\mathrm{Bcl}-2$ are critical regulators of the 17 mitochondrial pathway. They can modulate the mitochondrial outer membrane 18 permeability to control the release of mitochondrial cytochrome c $[26,27]$. The interaction between Bcl-2 and Bax plays a decisive role in apoptosis: Bcl-2 inhibits apoptosis by inhibiting the release of cytochrome c, and Bax induces apoptosis by 21 promoting cytochrome c release and various caspase-dependent signaling pathways 22 [28]. Increased caspase-3 activity is crucial for drug-induced apoptosis, as the 23 activation of caspase-3 is a hallmark of apoptosis and can be used to quantify the 24 caspase cascade. Caspase- 3 is triggered by either caspase- 8 or caspase-9, which acts 25 as a convergence point for different apoptosis signaling pathways [5, 28].

26 In our study, we determined the cytotoxic effects of EAFE on HepG2 cells and 
1 found that EAFE inhibited HepG2 cell proliferation (Fig. 1 and Fig. 2). We also

2 showed that treatment of HepG2 cells with EAFE could increase ROS generation and

3 induce apoptosis and arrest the cell cycle in the S phase (Fig. 2 and Fig. 4). In

4 addition, EAFE treatment promoted the induction of apoptosis and DNA damage in

5 HepG2 cells (Fig. 3). EAFE treatment also increased caspase-3 and caspase-9

6 activities (Fig. 5). Calcium ion is one of the key regulators of apoptosis induction via

7 ER stress. Higher level of $\mathrm{Ca}^{+2}$, as observed in our study, could be a consequence of

8 mitochondrial membrane damage after EAFE exposure (Fig. 4). Western blot analysis

9 revealed that the upregulation of Bax, AIF, Endo G, and cytochrome $\mathrm{c}$ and the corresponding downregulation of Bcl-2 proteins observed in our study may be one of the critical mechanisms through which EAFE induces apoptosis in HepG2 cells (Fig. 6). Therefore, we indicated that EAFE inhibited HepG2 cell growth and induced apoptosis through ROS-dependent endoplasmic reticulum stress.

14 Previous studies have shown that several plant extracts and active compounds such as Tulbaghia violacea Harv., Costus speciosus (J. Koenig) Sm., epigallocatechin-3-gallate, and silybin induce caspase-3-mediated apoptotic cell death 17 in hepatocellular carcinoma(Padmapriya et al., 2017)[29]. The pro-apoptotic effect of 18 shikonin is also caused by the disruption of intracellular $\mathrm{Ca}^{2+}$ homeostasis and 19 mitochondrial dysfunction, which involves enhanced $\mathrm{Ca}^{2+}$ and potassium $\left(\mathrm{K}^{+}\right)$efflux; caspase-3, caspase-8, and caspase- 9 activation; and Bcl-2 family protein modulation [30]. Neochamaejasmin A, one of the main active constituents of Stellera chamaejasme Linn., also triggered mitochondrial membrane potential disorder, which caused the release of a large amount of cytochrome $\mathrm{c}$ to the cytoplasm, as well as the upregulation of the levels of Bax and cleaved caspase-3 and downregulation of the 25 level of Bcl-2 in HepG2 cells. Taken together, these results implied that neochamaejasmin A could induce HepG2 and BEL-7402 cell apoptosis via the 
1 ROS-mediated mitochondrial apoptotic pathway [31].

2 MDA is a marker of lipid peroxidation, and its increase is related to the negative

3 effects on fluidity and damage to cell membranes; it is implicated as the most

4 important parameter for the extent of oxidative stress. GSH acts as a major

5 antioxidant, protecting cells from the damaging effects of ROS and apoptotic cell

6 death. GSH exists in all cells and is the only available scavenger of hydrogen

7 peroxide in the mitochondria; its depletion leads to severe mitochondrial damage.

8 Increased GSH levels have been found to play a crucial role in cancer progression and

9 resistance. Conversely, the depletion of cellular GSH levels in tumor cells through 10 chemotherapeutic intervention has been shown to decrease drug resistance and 11 increase therapeutic response [32]. GSH, SOD, and catalase play important roles in 12 the antioxidant system, and the changes in their content or activity reflect oxidative 13 damage to cells [33].

14 Our data revealed that treatment with EAFE significantly enhanced intracellular ROS production and MDA levels; decreased GSH level; and increased GSH-Px, SOD, and catalase activities in HepG2 cells (Fig. 7). This is an important finding since 17 HepG2 cells express high intracellular levels of GSH, which facilitates the growth of 18 HepG2 cells and confers them resistance to current therapies. Considering that cells can undergo apoptosis in response to GSH depletion, EAFE treatment might trigger events leading to the accumulation of intracellular free radicals and initiation of apoptotic cascades, which may contribute, at least in part, to the reduction in HepG2 cell viability. Several studies have indicated that ROS and MDA production play a crucial role in cell cycle progression and apoptosis $[34,35]$. Many anticancer agents

24 have been reported to mediate their activity through mitochondrial events such as the 25 depletion of glutathione, production of ROS, and activation of intrinsic apoptosis pathways. Natural products have played a significant role in the development of 
anticancer drugs [36].

2 New anticancer approaches can be explored using traditional Chinese medicinal

3 plants, which are an excellent source of chemotherapeutic agents with various

4 biological activities and have remarkable potential therapeutic value. Natural products

5 have always played a pivotal role in anticancer drug discovery, with the majority of

6 anticancer drugs being either pure natural products or their synthetic/semisynthetic

7 derivatives. Flavonoids, plant polyphenolic compound derivatives of natural origin,

8 have been shown to have a wide range of putative biological activities. Herb plants

9 have traditionally been used to prevent or treat various human diseases [ $9,14,37,38]$.

10 Natural products have been considered as the major sources of chemotherapeutic

11 drugs in the treatment of hepatocellular carcinoma [39].

12 In our study, we evaluated the phenolic compound contents of EAFE, NBFE, and WFE by using HPLC. The highest polyphenol content in EAFE was RA and CA (Fig.

$14 \mathbf{8}$ and Table 1). In structure-activity relationships, RA is an ester of caffeic acid and 3,4-dihydroxyphenyllactic acid. RA and CA are common water-soluble phenolic compounds in many well-known herbs of the Lamiaceae family [40]. In addition to antioxidant activity, RA also has pro-oxidant activity. Murakami et al. reported that the cytotoxicity of RA may be related to its pro-oxidant action, and that RA increases ROS and induces apoptosis in Jurkat and peripheral $\mathrm{T}$ cells via the mitochondrial pathway [41]. RA promotes an increase in intracellular GSH concentrations. However, the opposite effect of a decrease in GSH caused by flavonoids has been widely reported. Both antioxidant and pro-oxidant activities have been observed at different doses of phenolic compounds [42]. RA has been confirmed to inhibit the proliferation of small cell lung cancer cells (NCI-H82), human prostate cancer cells (DU-145), and human chronic myeloid leukemia cells (K-562) in vitro [43]. Some in vitro studies have shown that RA has certain protective effects against lung cancer, colon cancer, 
1 breast cancer, gastric carcinoma, and liver cancer. Furthermore, RA remarkably

2 suppresses cancer cell proliferation, induces cell apoptosis, and arrests the cell cycle,

3 which are characteristics associated with drugs that effectively prevent tumors [44].

4 CA (3,4-dihydroxycinnamic acid), is a polyphenol produced through the secondary

5 metabolism of vegetables, including olives, coffee beans, fruits, potatoes, carrots, and

6 propolis, and constitutes the main hydroxycinnamic acid found in the diet of humans

7 [45]. The mitochondrial membrane potential was found to be reduced in the colon

8 cancer cell line HCT-15 when cells were exposed to CA [46]. CA also exhibits an

9 anti-cancer effect, and a previous study showed that CA promoted NSCLC A549 cell 10 proliferation and enhanced PTX-induced proliferation in A549 cells [47]. Min et al. 11 revealed the synergistic anticancer activity of the combined use of CA with paclitaxel.

12 In addition, it has shown to have immunomodulatory and anti-cancer functions in 13 human metastatic cervical carcinoma, ovarian carcinoma, and fibrosarcoma [48].

14 FA (4-hydroxy-3-methoxycinnamic acid) is a plant-derived polyphenolic 15 compound found in several fruits and vegetables such as orange, tomato, carrot, sweet 16 corn, wheat, and rice bran, as well as in the natural extracts of herbs, spices, and 17 coffee. FA is receiving greater attention because of its wide range of therapeutic 18 effects against various diseases, including cancer, diabetes, and cardiovascular and 19 neurodegenerative diseases [49]. Other studies have also revealed the therapeutic 20 efficacy of cinnamic acid derivatives such as ferulic acid, caffeic acid, and 21 chlorogenic acids for treating cancers [50]. FA upregulated Bax and downregulated 22 Bcl-2 to induce apoptosis in osteosarcoma cells. Similarly, FA induced the expression 23 of Bax, caspase-3, and caspase-9 in fibrosarcoma cells [51]. FA exhibited remarkable 24 anti-thrombotic, hypolipidemic, and anti-inflammatory activities. Moreover, Luo et al. 25 reported that FA showed cytotoxic effects in HeLa cells and CaSki cervical carcinoma 26 cells [52]. 
1 Chlorogenic acid (CGA) is a polyphenol abundantly present in various plant foods

2 such as coffee beans and apples and is formed by the esterification of caffeic and

3 quinic acids. CGA stimulated apoptosis and inhibited cell proliferation in a human

4 acute promyelocytic leukemia cell line. It induced the expression of several caspases

5 and mitochondria-dependent pathways to promote apoptotic cell death in U937

6 human leukemia cells [53]. Hou et al. reported that CGA dose-dependently inhibited

7 the growth of HCT116 and HT29 colon cancer cells in vitro, induced cell cycle arrest

8 in the $\mathrm{S}$ phase, and inhibited the activation of extracellular signal-related kinases in

9 both cell types [54]. Epidemiological studies have shown that CGA is associated with

10 many health benefits, including cancer prevention. The biological activities of CGA

11 are based on the regulation of proliferation, apoptosis, and cell cycle signaling,

12 leading to cell growth inhibition [55, 56]. Quercetin can upregulate intracellular ROS

13 levels, thereby triggering cell death. Furthermore, quercetin can induce cell cycle

14 arrest and apoptosis of hepatocellular carcinoma cells by stabilizing or inducing p53.

$15 \mathrm{p} 53$, a tumor suppressor protein involved in cancer prevention, can regulate the cell 16 cycle, apoptosis, and DNA repair [57].

17 Polyphenols are abundant micronutrients in our diet and are known to have health 18 effects. Polyphenols, a class of secondary metabolites in plants and fungi, are 19 ubiquitously distributed in relatively high concentrations in all foods and plants [58].

20 Phytomedicines have been widely documented to directly or indirectly target multiple 21 signaling pathways and networks in cancer cells (Luo et al., 2019)[11]. Taken 22 together, our results strongly suggest that RA, CA, and FA together with other 23 polyphenols in EAFE can inhibit HepG2 cell growth and induce apoptosis through the 24 mitochondria-mediated pathway and ROS-mediated endoplasmic reticulum stress. 
1 In conclusion, we showed that RA, CA, and FA were the major polyphenolic

2 components that were abundant in the EAFE of $G$. hederacea L.. Our results are in

3 agreement with those of previous studies. Therefore, we concluded that the flavonoids

4 in EAFE may significantly inhibit the proliferation of HepG2 cells, induce apoptosis,

5 and arrest the cell cycle in the $\mathrm{S}$ phase. The apoptogenic activity of EAFE involved

6 the induction of $\mathrm{ROS}, \mathrm{Ca}^{2+}, \mathrm{GSH}$ depletion, mitochondrial membrane potential

7 disruption, caspase 3 and 9 activation, and Bax/Bcl-2 ratio increase. A schematic

8 representation of the mechanism of EAFE action is shown in Fig. 9.

9

\section{Abbreviations}

11 AIF: apoptosis-inducing factor; CA: caffeic acid; CAT: catalase; CGA:

12 chlorogenic acid; DAPI: 4,6-diamino-2-phenylindole; EAFE: ethyl acetate

13 fraction extract; FA: ferulic acid; GPx: glutathione peroxidase; GSH: glutathione;

14 HWG: hot water extracts of G. hederacea; MDA: malondialdehyde; MMP:

15 mitochondrial membrane potential; NBFE: $n$-butanol fraction extract; RA: rosmarinic

16 acid; ROS: reactive oxygen species; SOD: superoxide dismutase; WFE: water fraction

17 extract.

\section{Conflict of interest}

20 The authors declare no conflict of interest.

\section{Author contributions}

23 Conceived and designed the experiments: S.-T.C. (stchou@pu.edu.tw)

24 Performed the experiments: Y.-J.L. (lili021919@hotmail.com), H.-T.M.

25 (s9622029@gm.pu.edu.tw ) and Y.-H.C. (yihua62@pu.edu.tw)

26 Analyzed the data: Y.-J.L., H.-T.M., Y.-H.C. and W.-W.C. (wwchao@ mail.knu.edu.tw) 
1 Wrote the manuscript: W.-W.C.

2 Reviewed the manuscript and coordinated the submission processes: S.-T.C.

3 All authors had reviewed and approved the final version of manuscript for

4 submission.

5

$6 \quad$ Funding

7 The authors are grateful for financial support from the Ministry of Science and

8 Technology of the Republic of China (NSC 102-2313-B-126 -004 -MY3).

9

Availability of data and materials

11 The datasets used in this study are available from the corresponding author upon

12 reasonable request.

13

14 Ethics approval and consent to participate

15 Not applicable.

16

17 Consent for publication

18 Not applicable.

19

20

Competing interests

21 The authors declare that they have no competing interests.

22

23

Conflict of interest

24 The authors declare no conflict of interest.

25

26 References

27 1. Wong R, Frenette C. Updates in the management of hepatocellular carcinoma. 
Gastroenterol Hepatol. 2011;7:16-24.

2. Aysegul O. Global epidemiology of hepatocellular carcinoma: an emphasis on

3 demographic and regional variability. Clin Liver Dis. 2017;19:223-38.

$43^{3}$ Cicho $^{\circ}$-Lach H, Michalak A. Oxidative stress as a crucial factor in liver diseases.

$5 \quad$ World J Gastroenterol. 2014;20:8082-91.

6 4. Redza-Dutordoir M, Averill-Bates DA. Activation of apoptosis signalling pathways

7 by reactive oxygen species. Biochim Biophys Acta. 2016;1863:2977-92.

8 5. You BR, Moon HJ, Han YH, Park WH. Gallic acid inhibits the growth of HeLa

9 cervical cancer cells via apoptosis and/or necrosis. Food Chem Toxicol. 2010;48:1334-40.

6. Rasola A, Bernardi P. The mitochondrial permeability transition pore and its involvement in cell death and in disease pathogenesis. Apoptosis 2007;12:815-33.

7. Singh PK, Kumar A. Mitochondria mediates caspase-dependent and independent 2016;2:16034-44.

8. Chao WW, Cheng YW, Chen YR, Lee SH, Chiou CY, Shyur LF. Phyto-sesquiterpene lactone deoxyelephantopin and cisplatin synergistically suppress lung metastasis of B16 melanoma in mice with reduced nephrotoxicity. Phytomedicine. 2019;56: 194-06.

9. Chou ST, Ho BY, Tai YT, Huang CJ, Chao WW. Bidirect effects from cisplatin combine with rosmarinic acid (RA) or hot water extracts of Glechoma hederacea (HWG) on renal cancer cells. Chin Med. 2020;15:77-89.

10. Mukherjee AK, Basu S, Sarkar N, Ghosh AC. Advances in cancer therapy with plant based natural products. Curr Med Chem. 2001;8:1467-86.

11. Luo H, Vong CT, Chen H, Gao Y, Lyu P, Qiu L, Zhao M, Liu Q, Cheng Z, Zou J, Yao P, Gao C, Wei J, Ung COL, Wang S, Zhong Z, Wang Y. Naturally 
occurring anti-cancer compounds: shining from Chinese herbal medicine. Chin Med. 2019;14:48-5.

12. Newman DJ, Cragg GM. Natural Products as Sources of New Drugs from 1981 to 2014. J Nat Prod. 2016;79:629-661.

13. An HJ, Jeong HJ, Um JY, Kim HM, Hong SH. Glechoma hederacea inhibits inflammatory mediator release in IFN- $\gamma$ and LPS-stimulated mouse peritoneal macrophages. J Ethnopharmacol. 2006;106:418-24.

14. Chou ST, Lin TH, Peng HY, Chao, WW. Phytochemical profile of hot water extract of Glechoma hederacea and its antioxidant, and anti-inflammatory activities. Life Sci. 2019;231:116519-28.

15. Lin SY, Wang YY, Chen WY, Liao SL, Chou ST, Yang CP, Chen CJ. Hepatoprotective activities of rosmarinic acid against extrahepatic cholestasis in rats. Food Chem Toxicol. 2017;108:214-23.

16. Milovanovic M, Zivkovic D, Vucelic-Radovic B. Antioxidant effects of Glechoma hederacea as a food additive. Nat Prod Commun. 2010;5:61-63.

17. Qiao Z, Koizumi Y, Zhang M, Natsui M, Flores MJ, Gao L, Yusa K, Koyota S, Sugiyama T. Anti-melanogenesis effect of Glechoma hederacea L. extract on B16 murine melanoma cells. Biosci Biotechnol Biochem. 2012;76:1877-83.

18. Wang YY, Lin SY, Chen WY, Liao SL, Wu CC, Pan PH, Chou ST, Chen CJ. Glechoma hederacea extracts attenuate cholestatic liver injury in a bile duct-ligated rat model. J. Ethnopharmacol. 2017;204:58-66.

19. Kuo HS, Tsai HC, Lin YL, Yang JS, Huang AC, Yang MD, Hsu SC, Chung MC, Wood WG, Chung JG. Mitochondrial-dependent caspase activation pathway is involved in baicalein-induced apoptosis in human hepatoma J5 cells. Int J Oncol. 2009;35: 717-24.

20. Kao TK, Ou YC, Raung SL, Chen WY, Yen YJ, Lai CY, Chou ST, Chen CJ. 
Graptopetalum paraguayense E. Walther leaf extracts protect against brain injury in ischemic rats. Am J Chin Med. 2010;38:495-16.

21. Long FY, Chen YS, Zhang L, Kuang X, Yu Y, Wang LF, Liu XJ, Wang L, Zhou YF, Sang N, Du JR. Pennogenyl saponins induce cell cycle arrest and apoptosis in human hepatocellular carcinoma HepG2 cells. J Ethnopharmacol. 2015;162:112-20.

22. Pham HHT, Seong YA, Ngabire D, Oh CW, Kim GD. Cyperus amuricus induces G1 arrest and apoptosis through endoplasmic reticulum stress and mitochondrial signaling in human hepatocellular carcinoma Hep3B cells.J Ethnopharmacol. 2017;208:157-164

23. Zhao Y, Jing Z, Lv J, Zhang Z, Lin J, Cao X, Zhao Z, Liu P, Mao W. Berberine activates caspase-9/cytochrome c-mediated apoptosis to suppress triple-negative breast cancer cells in vitro and in vivo. Biomed Pharmacother. 2017;95:18-24.

24. Kroemer G, Galluzzi L, Brenner, C. Mitochondrial membrane permeabilization in cell death. Physiol. Rev. 2007;87:99-63.

25. Cui Q, Wang JQ, Assaeaf YG, Ren L, Gupta P, Wei L, Ashby Jr CR, Yang DH, Chen ZS. Modulating ROS to overcome multidrug resistance in cancer. Drug Resist. Update. 2018;41:1-25.

26. Bras M, Queenan B, Susin SA. Programmed cell death via mitochondria: different modes of dying. Biochemistry (Mosc). 2005;70:231-39.

27. D’Archivio M, Santangelo C, Scazzocchio B, Varì R, Filesi C. Modulatory effects of polyphenols on apoptosis induction: relevance for cancer prevention. Int $\mathbf{J}$ Mol Sci. 2008;9:213-28.

28. Zhang Y, Yang X, Ge X, Zhang F. Puerarin attenuates neurological deficits via Bcl-2/Bax/cleaved caspase-3 and Sirt3/SOD2 apoptotic pathways in subarachnoid hemorrhage mice. Biomed Pharmacother. 2019;109:726-33. 
1 29. Padmapriya R, Gayathri L, Ronsard L, Akbarsha MA, Raveendran R. In vitro anti-proliferative effect of Tephrosia purpurea on human hepatocellular carcinoma cells. Phcog Mag. 2017;13:S16-S21.

30. Wang H, Liu Z, Li X, Zhao R, Pu Y, Wu H, Guan W. Shikonin causes apoptosis by disrupting intracellular calcium homeostasis and mitochondrial function in human hepatoma cells. Exp Ther Med. 2018;15:1484-92.

31. Ding Y, Xia Q, Liu W, Pan Z, Fan X, Chen X, Li M, Zhao W, Li D, Zheng Q. Neochamaejasmin A induces mitochondrial-mediated apoptosis in human hepatoma cells via ROS-dependent activation of the ERK1/2/JNK signaling pathway. Oxi Med Cell Longev. 2020;2020:3237150-61.

32. Traverso, N., Ricciarelli, R., Nitti, M., Marengo, B., Furfaro, A.L., Pronzato, M.A., Marinari, U.M., Domenicotti, C., Role of glutathione in cancer progression and chemoresistance.Oxid. Med. Cell Longev. 2012;2013:972913-22.

33. Espinosa-Diez C, Miguel V, Mennerich D, Kietzmann T, Sanchez-Perez P, Cadenas S, Lamas S. Antioxidant responses and cellular adjustments to oxidative stress. Redox Biol. 2015;6:183-97.

34. Oliveira JMPF, Santos C, Fernandes E. Therapeutic potential of hesperidin and its aglycone hesperetin: cell cycle regulation and apoptosis induction in cancer models. Phytomedicine. 2020;73:152887-900.

35. Xie H, Li X, Chen Y, Lang M, Shen Z, Shi L. Ethanolic extract of Cordyceps cicadae exerts antitumor effect on human gastric cancer SGC-7901 cells by inducing apoptosis, cell cycle arrest and endoplasmic reticulum stress. J Ethnopharmacol. 2019;231:230-40.

36. Gupta SC, Kim JH, Prasad S, Aggarwal BB. Regulation of survival, proliferation, invasion, angiogenesis, and metastasis of tumor cells through modulation of inflammatory pathways by nutraceuticals. Cancer Metastasis Rev. 
2010;29:405-34.

37. Ho JW, Leung YK, Chan CP. Herbal medicine in the treatment of cancer.Curr Med Chem Anticancer Agents. 2002;2:209-14.

38. Setzer WN, Setzer MC. Plant-derived triterpenoids as potential antineoplastic agents. Mini Rev Med Chem. 2003;3:540-56.

39. Huang RZ, Huang XC, Zhang B, Jia HY, Liao ZX, Wang HS. 16-O-caffeoyl-16-hydroxylhexadecanoic acid, a medicinal plant-derived phenylpropanoid, induces apoptosis in human hepatocarcinoma cells through ROS-dependent endoplasmic reticulum stress. Phytomedicine. 2018;41:33-44.

40. Khojasteh A, Mirjalili MH, Hidalgo D, Corchete P, Palazon J. New trends in biotechnological production of rosmarinic acid. Biotechnol Lett. 2014;36:2393-6.

41. Murakami K, Haneda M, Qiao S, Naruse M, Yoshino M. Prooxidant action of rosmarinic acid: transition metal-dependent generation of reactive oxygen species. Toxicol. in Vitro. 2007;21:613-17.

42. Gonzalez-Vallinas M, Reglero G, Ramirez de Molina A. Rosemary (Rosmarinus officinalis L.) extract as a potential complementary agent in anticancer therapy. Nutr. Cancer. 2015;67:1221-29.

43. Wang L, Yang H, Wang C, Shi X, Li K. Rosmarinic acid inhibits proliferation and invasion of hepatocellular carcinoma cells SMMC 7721 via PI3K/AKT/mTOR signal pathway. Biomed Pharmacother. 2019;120:109443-51.

44. Ma Z, Yang J, Yang Y, Wang X, Chen G, Shi A, Lu Y, Jia S, Kang X, Lu L. Rosmarinic acid exerts an anticancer effect on osteosarcoma cells by inhibiting DJ-1 via regulation of the PTEN-PI3K-Akt signaling pathway. Phytomedicine. 2020;68: 153186-210.

45. Espíndola KMM, Ferreira RG, Narvaez LEM, Silva Rosario ACR, da Silva AHM, 
Silva AGB, Vieira APO, Monteiro MC. Chemical and pharmacological aspects of caffeic acid and its activity in hepatocarcinoma. Front. Oncol. 2019;9:541-50.

46. Jaganathan SK. Growth inhibition by caffeic acid, one of the phenolic constituents of honey, in HCT 15 colon cancer cells. Sci World J. 2012;2012:372345-52.

47. Sirota R, Gibson D, Kohen R. The timing of caffeic acid treatment with cisplatin determines sensitization or resistance of ovarian carcinoma cell lines. Redox Biol. 2017;11:170-75.

48. Min J, Shen H, Xi W, Wang Q, Yin L, Zhang Y, Yu Y, Yang Q, Wang Z. Synergistic anticancer activity of combined use of caffeic acid with paclitaxel enhances apoptosis of non-small-cell lung cancer H1299 cells in vivo and in vitro. Cell Physiol. Biochem. 2018;48:1433-42.

49. Sarwar T, Zafaryab M, Husain MA, Ishqi HM, Rehman SU, Rizvi MMA, Tabish M. Redox cycling of endogenous copper by ferulic acid leads to cellular DNA breakage and consequent cell death: A putative cancer chemotherapy mechanism. Toxicol Appl Pharmacol. 2015;289:251-261.

50. Tsai CM, Yen GC, Sun FM, Yang SF, Weng CJ. Assessment of the anti-invasion potential and mechanism of select cinnamic acid derivatives on human lung adenocarcinoma cells. Mol Pharm. 2013;10:1890-00.

51. Fahrioglu U, Dodurga Y, Elmas L, Secme M. Ferulic acid decreases cell viability and colony formation while inhibiting migration of MIA $\mathrm{PaCa}-2$ human pancreatic cancer cells in vitro. Gene. 2016;576:476-82.

52. Luo L, Zhu S, Tong Y, Peng S. Ferulic acid induces apoptosis of HeLa and Caski cervical carcinoma cells by down-regulating the phosphatidylinositol 3-kinase (PI3K)/Akt signaling pathway. Med Sci Monit. 2020;26:e920095-101.

53. Yang JS, Liu CW, Ma YS, Weng SW, Tang NY, Wu SH, Ji BC, Ma CY, Ko YC, Funayama S, Kuo CL. Chlorogenic acid induces apoptotic cell death in U937 
leukemia cells through caspase- and mitochondria-dependent pathways. In Vivo. 2012;26:971-978.

3 54. Hou N, Liu N, Han J, Yan Y, Li J. Chlorogenic acid induces reactive oxygen 4 species generation and inhibits the viability of human colon cancer cells. Anti-Cancer Drugs. 2017;28:59-65.

6 55. Yan Y, Liu N, Hou N, Dong L, Li J. Chlorogenic acid inhibits hepatocellular carcinoma in vitro and in vivo. J Nutr Biochem. 2017;46:68-73.

8 56. Yamagata K, Izawa Y, Onodera D, Tagami M. Chlorogenic acid regulates

9 apoptosis and stem cell marker-related gene expression in A549 human lung cancer cells. Mol Cell Biochem. 2018;441:9-19.

57. Jeon JS, Kwon S, Ban K, Hong YK, Ahn C, Sung C, Choi I. Regulation of the intracellular ROS level is critical for the antiproliferative effect of quercetin in the hepatocellular carcinoma cell line HepG2. Nutr Cancer. 2019;71:861-69.

58. Van De Wier B, Koek GH, Bast A, Haenen GR. The potential of flavonoids in the treatment of non-alcoholic fatty liver disease. Crit Rev Food Sci Nutr. 2017;57: 834-55. 
Table 1 The polyphenol contents of EAFE, NBFE, and WFE.

\section{Figure captions}

4 Fig. 1. Effect of the hot water extract of Glechoma hederacea L. (HWG) and subfraction extracts, including ethyl acetate fraction extract (EAFE), $n$-butanol fraction extract (NBFE), and water fraction extract (WFE), on the cell viability of HepG2 cells. Each value represents mean \pm S.D. $(n=3)$. Different letters (a-i) denote significant difference among groups $(p<0.05)$.

Fig. 2. Ethyl acetate fraction extract of Glechoma hederacea L. (EAFE) exhibited antiproliferative activity against HepG2 cells. (A) Cell viability of HepG2 cells in the presence of different concentrations of EAFE for 24 h by using MTT assay. (B) Cell cycle distribution and (C) cells apoptosis (Sub-G1 peak) of HepG2 cells treated with $350 \mu \mathrm{g} / \mathrm{mL}$ of EAFE for $12-48 \mathrm{~h}$. The cell cycle distribution and apoptosis of the cells were determined before the extract treatment and used as control. Each value represents mean \pm S.D. $(n=3)$. Different letters $(\mathrm{a}-\mathrm{f})$ denote significant difference among groups $(p<0.05)$. An asterisk indicates significant difference $(p<0.05)$ from $0 \mathrm{~h}$.

Fig. 3 Effect of ethyl acetate fraction extract (EAFE) on the induction of apoptosis and DNA damage in HepG2 cells treated with $350 \mu \mathrm{g} / \mathrm{mL}$ of EAFE for $12-48$ h. Cells were stained with DAPI fluorescence microscopy (200X) and fluorescence intensity (A). DNA damage in HepG2 cells detected using comet assay by using fluorescence microscopy (200X) and comet movement (B). Different letters $(\mathrm{a}-\mathrm{d})$ denote significant difference among groups $(p<0.05)$. Each value represents mean \pm S.D. $(n=50)$. 
1 Fig. 4. Effect of ethyl acetate fraction extract (EAFE) on the level of (A) reactive oxygen species (ROS), (B) calcium release, and MMP (C) of HepG2 cells treated with $350 \mu \mathrm{g} / \mathrm{mL}$ of EAFE for $1-48 \mathrm{~h}$. The ROS of the cells were determined before the extract treatment and used as control. Different letters (a-g) denote significant difference among groups $(p<0.05)$. Each value represents mean \pm S.D. $(n=3)$.

Fig. 5. Effect of ethyl acetate fraction extract (EAFE) on the (A) caspase-3 and (B) caspase- 9 activity of HepG2 cells treated with $350 \mu \mathrm{g} / \mathrm{mL}$ of EAFE for $12-48$ h. The caspase- 3 and caspase- 9 activities of the cells were determined before the extract treatment and used as control. Different letters $(\mathrm{a}-\mathrm{d})$ denote significant difference among groups $(p<0.05)$. Each value represents mean \pm S.D. $(n=3)$.

Fig. 6. Effect of ethyl acetate fraction extract (EAFE) on the protein expression of Bcl-2, Bax, AIF, Endo G, and cytochrome c in HepG2 cells treated with 350 $\mu \mathrm{g} / \mathrm{mL}$ of EAFE for $12-48 \mathrm{~h}$. The Bcl-2, Bax, AIF, Endo G, and cytochrome c, expression levels of the cells were determined before the extract treatment and used as control. Different letters $(\mathrm{a}-\mathrm{d})$ denote significant difference among groups $(p<0.05)$. Each value represents mean \pm S.D. $(n=3)$.

Fig. 7. Effect of ethyl acetate fraction extract (EAFE) on MDA levels (A), GSH levels (B), GSH-Px activity (C), SOD activity (D), and catalase activity (E) of HepG2 cells treated with $350 \mu \mathrm{g} / \mathrm{mL}$ of EAFE for $12-48 \mathrm{~h}$. The data are the mean \pm S.D. $(n=3)$. Different letters $(a-d)$ denote significant differences between groups $(P<0.05)$.

Fig. 8. The polyphenolic profiles of (A) standards, (B) EAFE (25 mg/mL), (C) NBFE (25 mg/mL), and (D) WFE (25 mg/mL) from G. hederacea L.. 1, gallic acid (4.83 $\mathrm{min}) ; 2$, catechin (13.3 min); 3, chlorogenic acid (13.97min); 4, caffeic 
acid (15.90 min); 5, daidzin (21.29 min); 6, ferulic acid (24.11 min); 7, rutin (26.00 $\mathrm{min}) ; 8$, genistin (27.95 $\mathrm{min}) ; 9$, rosmarinic acid (32.92 $\mathrm{min}) ; 10$, quercetin (40.71 $\mathrm{min})$; 11, genistein (46.87 $\mathrm{min})$; 12, flavone (55.12 $\mathrm{min}$ ).

4 Fig. 9. A proposed model illustrates the molecular mechanism and the overall 5 possible signaling pathways of ethyl acetate fraction extract (EAFE)-induced 6 apoptosis in HepG2 cells.

7 
1 Table 1 The polyphenol contents of EAFE, NBFE, and WFE

\begin{tabular}{lcccccc}
\hline \hline \multicolumn{1}{c}{ Compound } & $\begin{array}{c}\text { Retention time } \\
(\mathbf{m i n})\end{array}$ & $\begin{array}{c}\text { Linear regression } \\
\text { equation }\end{array}$ & $\begin{array}{c}\text { Correlation } \\
\text { coefficient }\left(\mathbf{R}^{2}\right)\end{array}$ & $\begin{array}{c}\text { Amount in EAFE } \\
(\mathbf{m g} / \mathbf{1 0 0 g})\end{array}$ & $\begin{array}{c}\text { Amount in NBFE } \\
(\mathbf{m g} / \mathbf{1 0 0 g})\end{array}$ & $\begin{array}{c}\text { Amount in WFE } \\
(\mathbf{m g} / \mathbf{1 0 0 g})\end{array}$ \\
\hline Gallic acid & 4.83 & $\mathrm{y}=57871 \mathrm{x}-213.06$ & 0.99 & - & - & - \\
Catechin & 13.3 & $\mathrm{y}=10647 \mathrm{x}+72.265$ & 0.99 & - & - & - \\
Chlorogenic acid & 13.97 & $\mathrm{y}=18867 \mathrm{x}-97.971$ & 0.99 & $201.10 \pm 10.48$ & $872.68 \pm 24.01$ & $401.11 \pm 23.06$ \\
Caffeic acid & 15.90 & $\mathrm{y}=40082 \mathrm{x}-165.19$ & 0.99 & $6107.04 \pm 160.16$ & $593.45 \pm 8.05$ & - \\
Daidzin & 21.29 & $\mathrm{y}=42711 \mathrm{x}+172.28$ & 0.99 & $11.42 \pm 1.04$ & $409.74 \pm 5.775$ & $16.59 \pm 1.23$ \\
Ferulic acid & 24.11 & $\mathrm{y}=35974 \mathrm{x}-217.03$ & 0.99 & $578.59 \pm 25.15$ & $663.86 \pm 14.47$ & $66.53 \pm 9.41$ \\
Rutin & 26.00 & $\mathrm{y}=24582 \mathrm{x}+79.342$ & 0.99 & $265.01 \pm 12.71$ & $464.33 \pm 15.57$ & $21.29 \pm 1.45$ \\
Genistin & 27.95 & $\mathrm{y}=51831 \mathrm{x}+134.2$ & 0.99 & $18.55 \pm 1.80$ & $451.81 \pm 43.95$ & $29.68 \pm 3.35$ \\
Rosmarinic acid & 32.92 & $\mathrm{y}=20539 \mathrm{x}-158.41$ & 0.99 & $17410.42 \pm 580.45$ & $16458.82 \pm 377.73$ & $286.54 \pm 17.93$ \\
Quercetin & 40.71 & $\mathrm{y}=43251 \mathrm{x}+78.501$ & 0.99 & $60.19 \pm 0.98$ & - & - \\
Genistein & 46.87 & $\mathrm{y}=87267 \mathrm{x}+255.68$ & 0.99 & $13.41 \pm 0.83$ & $2.73 \pm 0.71$ & - \\
Flavone & 55.12 & $\mathrm{y}=42346 \mathrm{x}+183.33$ & 0.99 & & - & - \\
\hline \hline
\end{tabular}

$2 \quad-:$ not detected

3 Each value represents mean \pm S.D. $(n=3)$.

4

5 


\section{Figures}

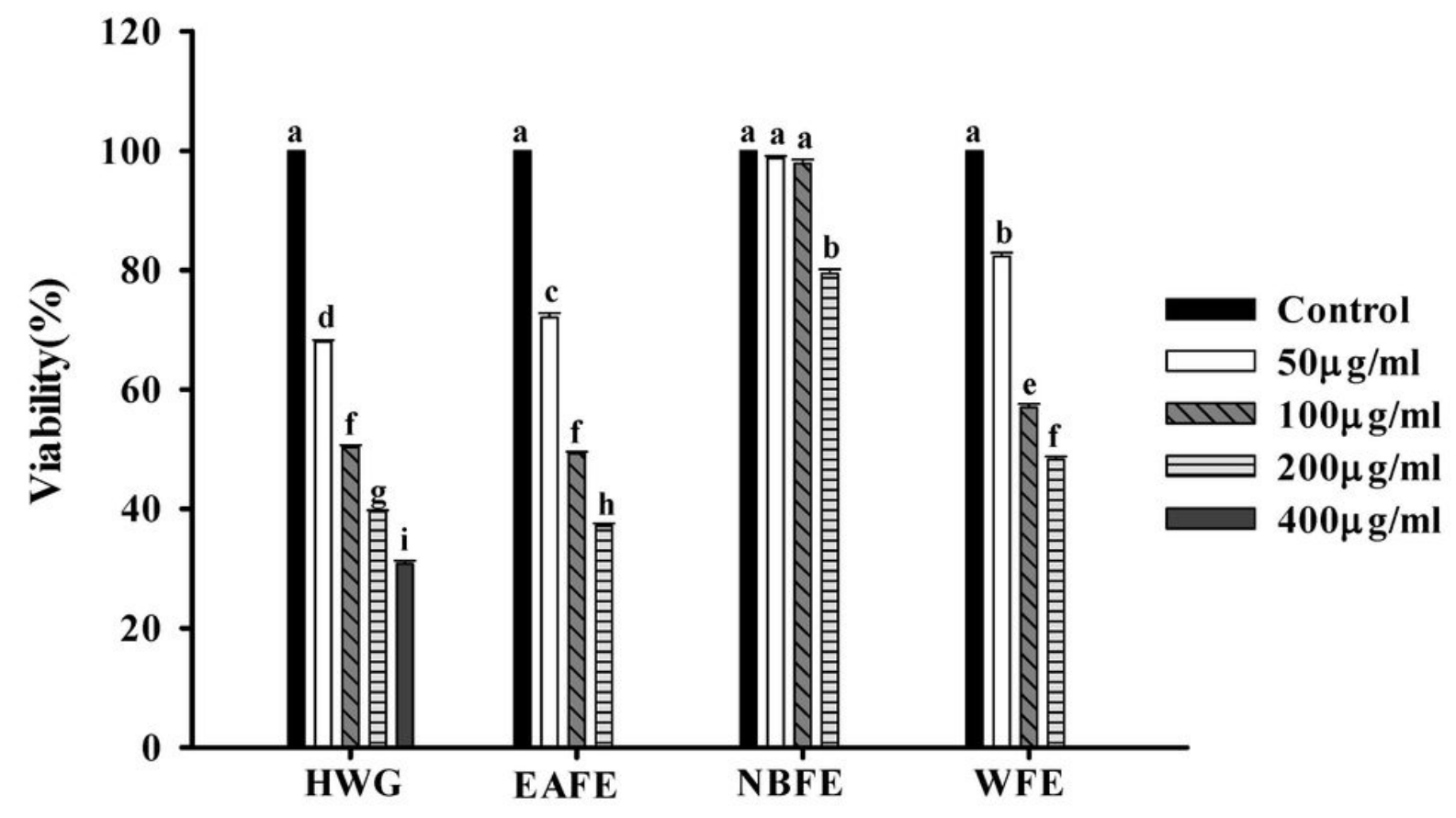

Figure 1

Effect of the hot water extract of Glechoma hederacea L. (HWG) and subfraction extracts, including ethyl acetate fraction extract (EAFE), n-butanol fraction extract (NBFE), and water fraction extract (WFE), on the cell viability of HepG2 cells. Each value represents mean \pm S.D. $(n=3)$. Different letters $(a-i)$ denote significant difference among groups $(p<0.05)$. 


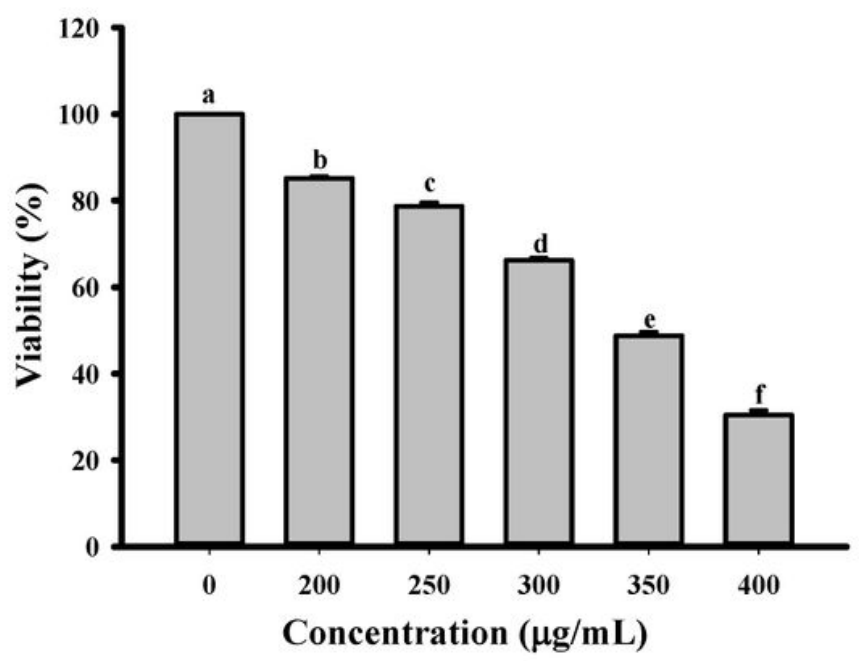

B

C
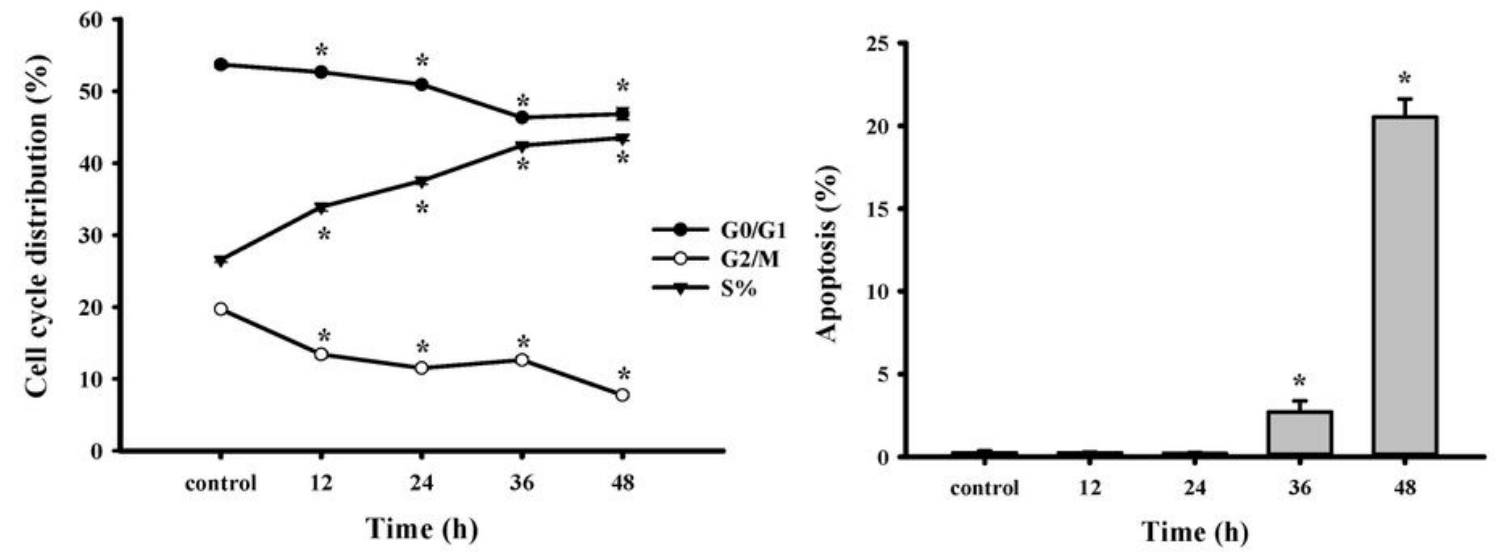

Figure 2

Ethyl acetate fraction extract of Glechoma hederacea L. (EAFE) exhibited antiproliferative activity against HepG2 cells. (A) Cell viability of HepG2 cells in the presence of different concentrations of EAFE for $24 \mathrm{~h}$ by using MTT assay. (B) Cell cycle distribution and (C) cells apoptosis (Sub-G1 peak) of HepG2 cells treated with $350 \mu \mathrm{g} / \mathrm{mL}$ of EAFE for 12-48 h. The cell cycle distribution and apoptosis of the cells were determined before the extract treatment and used as control. Each value represents mean \pm S.D. $(n=3)$. Different letters $(a-f)$ denote significant difference among groups $(p<0.05)$. An asterisk indicates significant difference $(p<0.05)$ from $0 \mathrm{~h}$. 


\section{A}
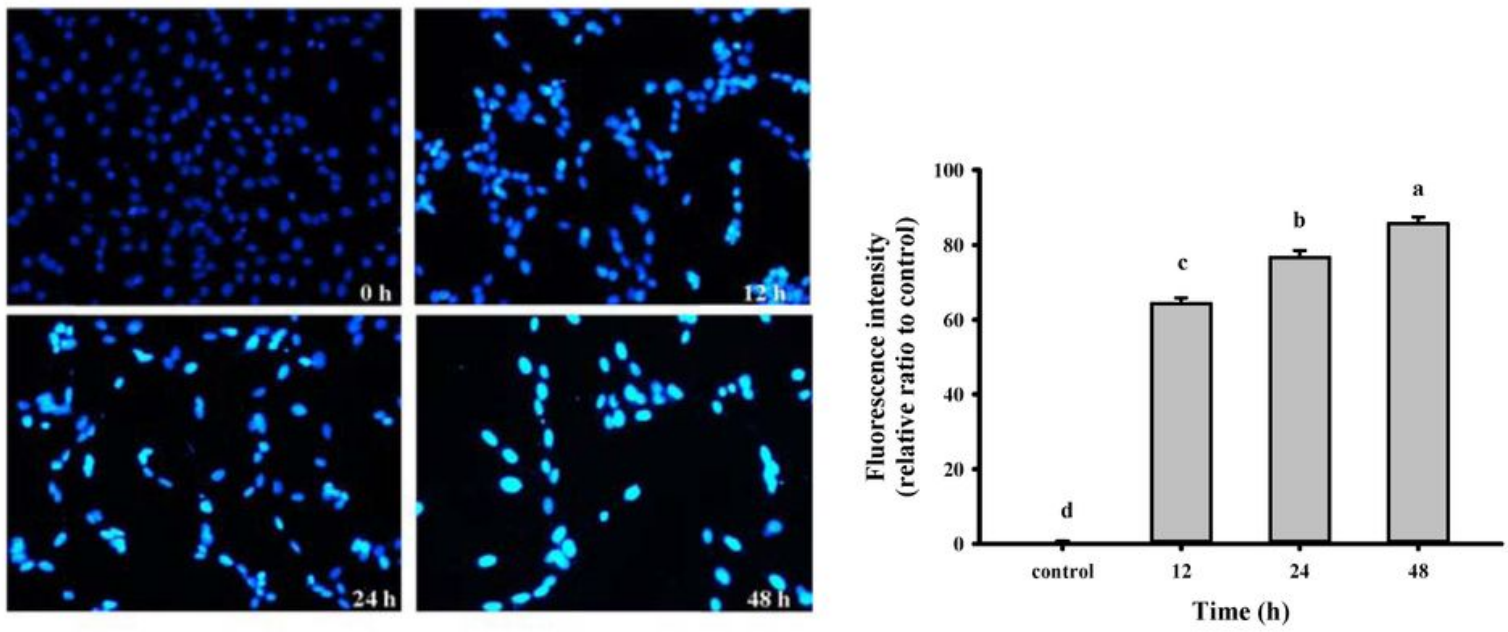

B
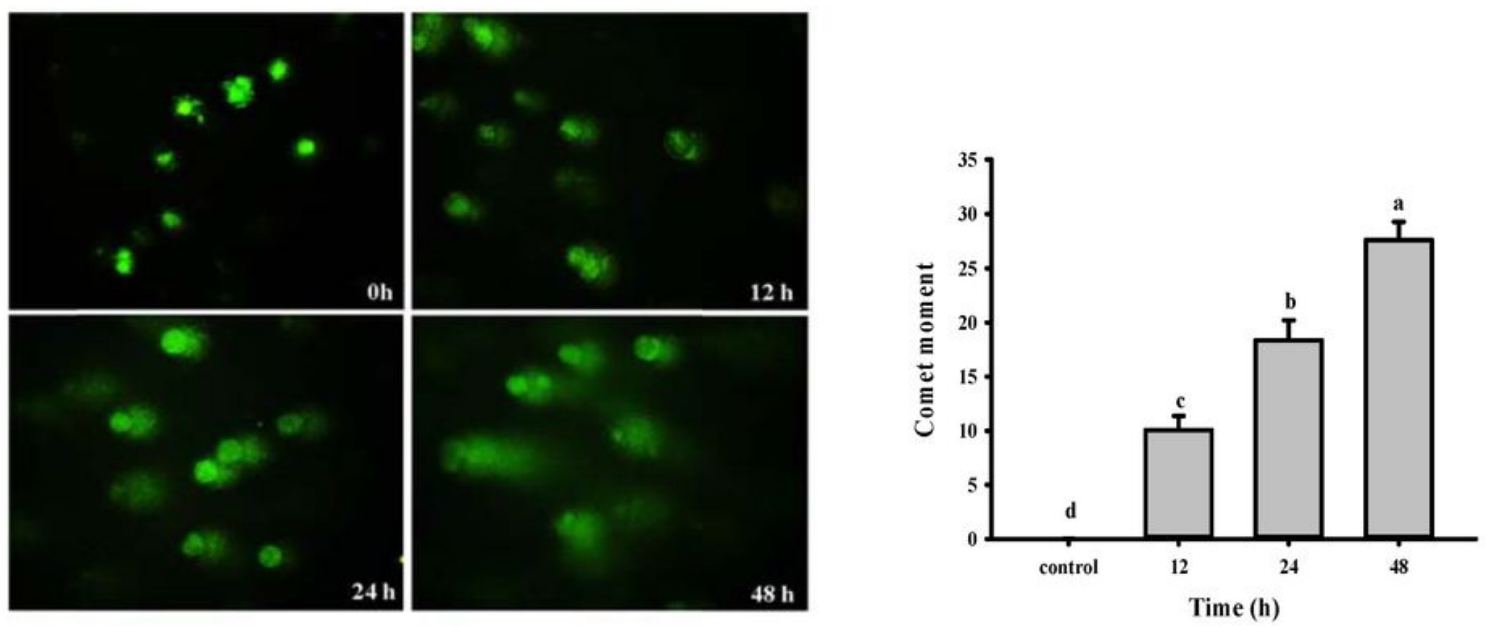

Figure 3

Effect of ethyl acetate fraction extract (EAFE) on the induction of apoptosis and DNA damage in HepG2 cells treated with $350 \mu \mathrm{g} / \mathrm{mL}$ of EAFE for 12-48 h. Cells were stained with DAPI fluorescence microscopy (200X) and fluorescence intensity (A). DNA damage in HepG2 cells detected using comet assay by using fluorescence microscopy (200X) and comet movement (B). Different letters $(a-d)$ denote significant difference among groups $(p<0.05)$. Each value represents mean \pm S.D. $(n=50)$. 

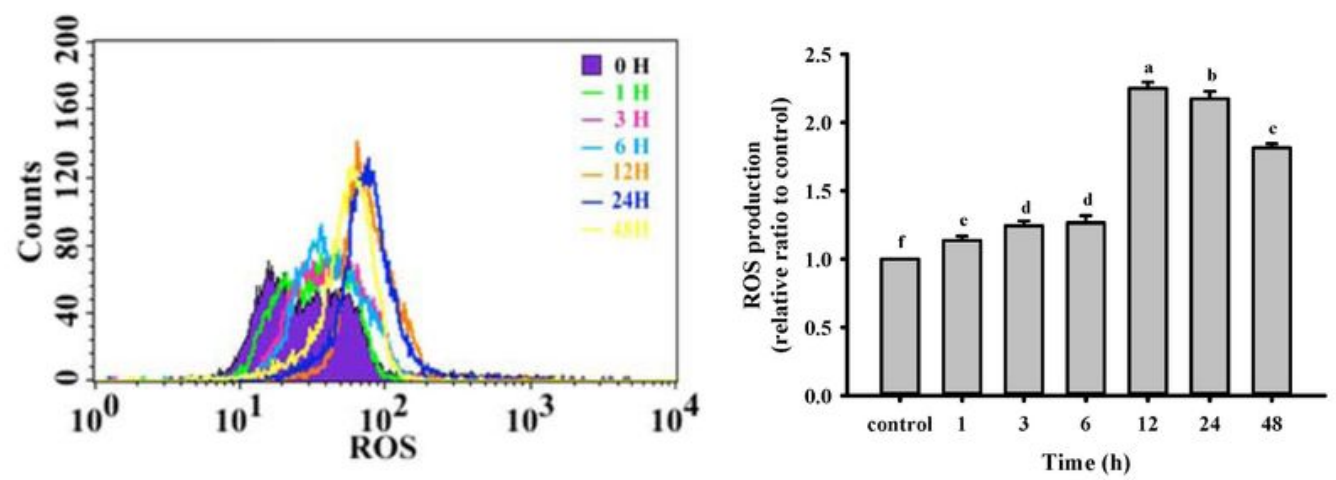

B
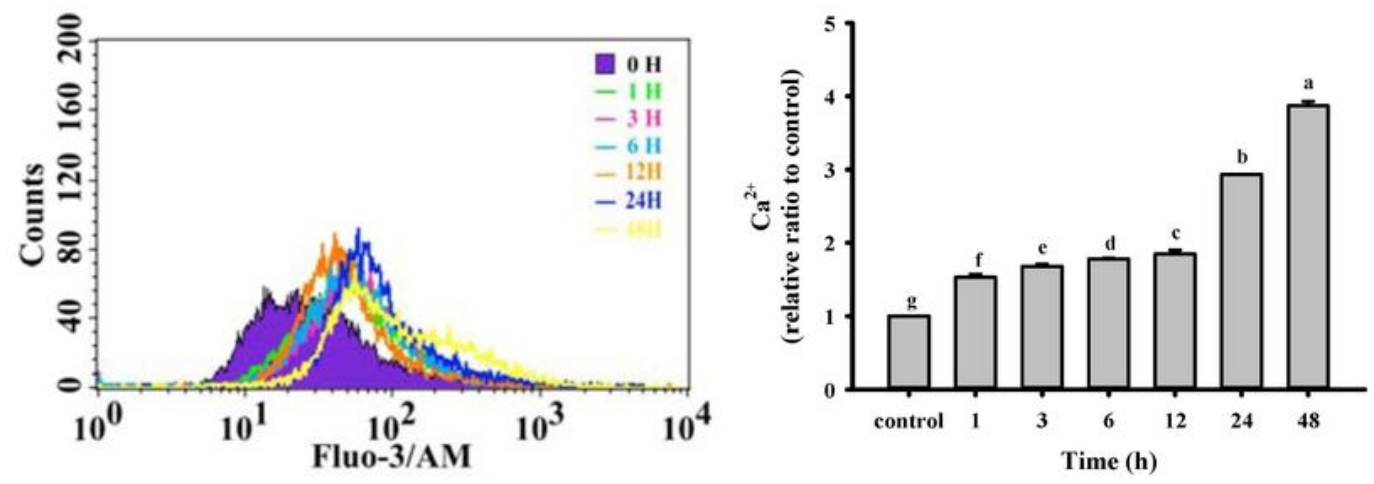

C
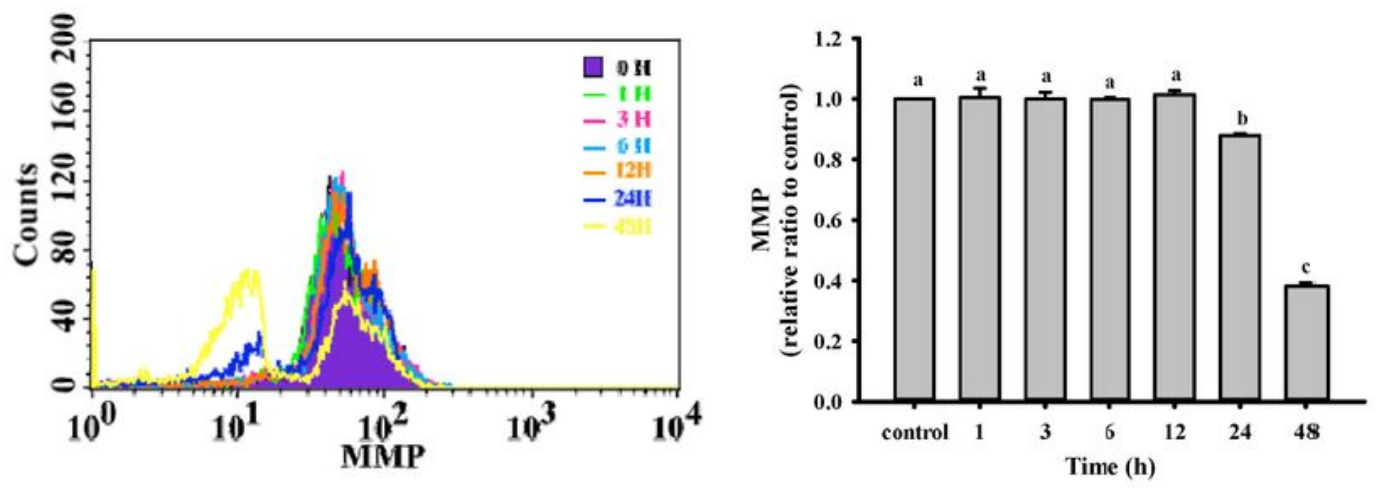

Figure 4

Effect of ethyl acetate fraction extract (EAFE) on the level of $(A)$ reactive oxygen species (ROS), (B) calcium release, and MMP (C) of HepG2 cells treated with $350 \mu \mathrm{g} / \mathrm{mL}$ of EAFE for 1-48 $\mathrm{h}$. The ROS of the cells were determined before the extract treatment and used as control. Different letters $(a-g)$ denote significant difference among groups $(p<0.05)$. Each value represents mean \pm S.D. $(n=3)$. 

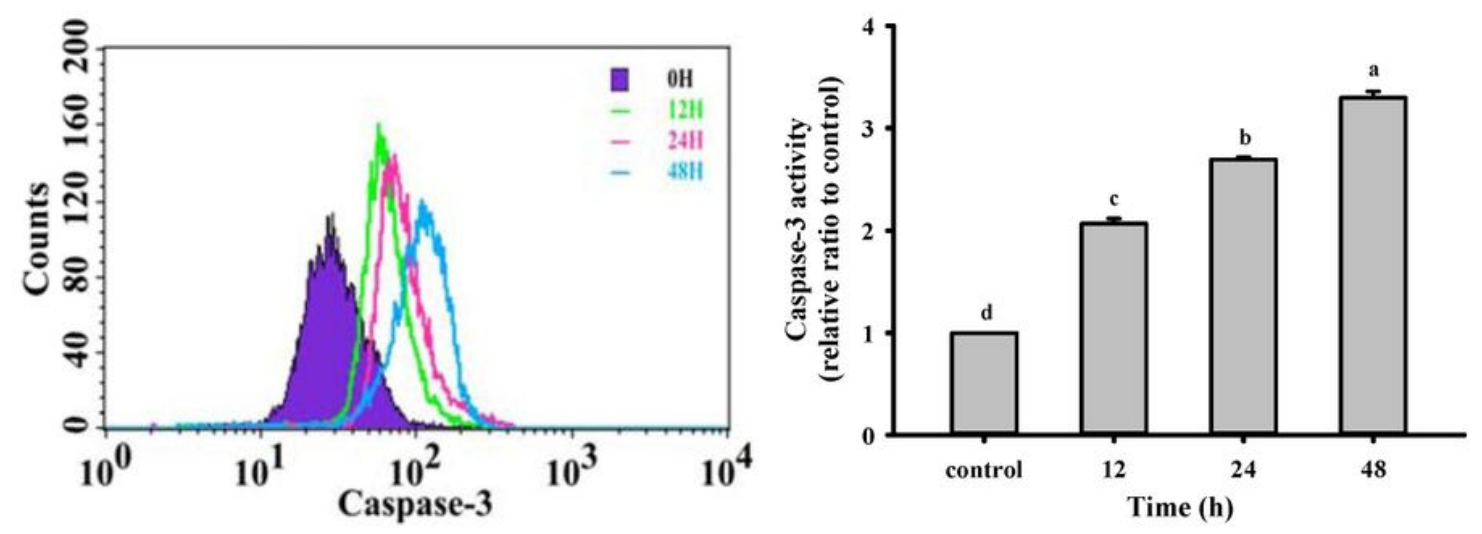

B
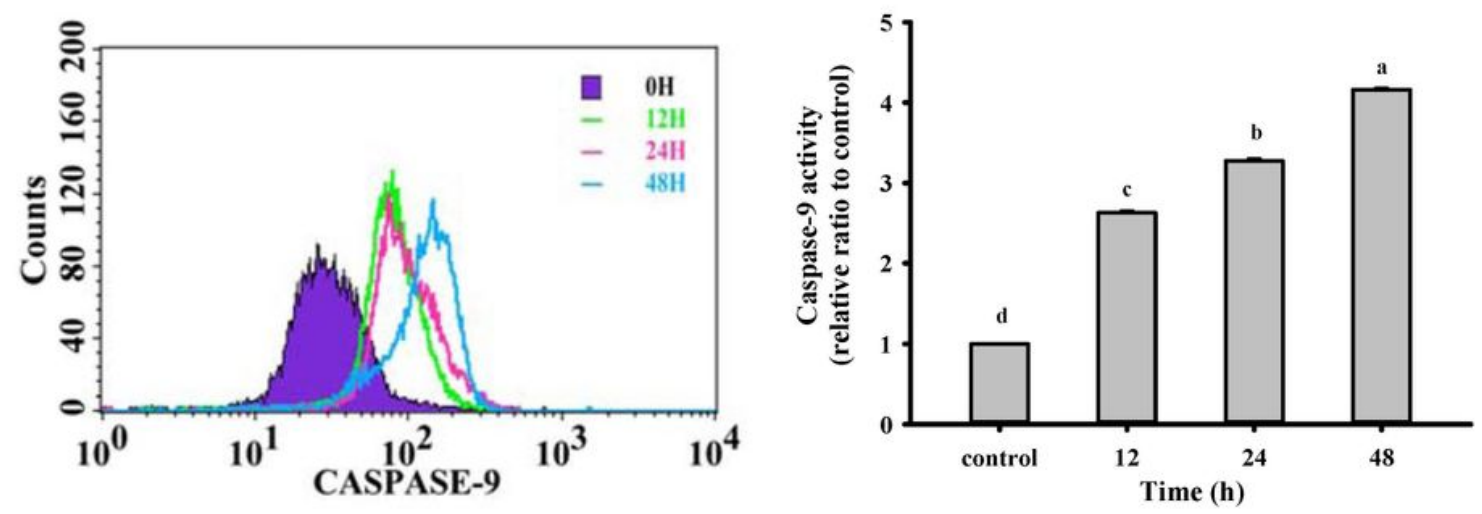

\section{Figure 5}

Effect of ethyl acetate fraction extract (EAFE) on the (A) caspase-3 and (B) caspase-9 activity of HepG2 cells treated with $350 \mu \mathrm{g} / \mathrm{mL}$ of EAFE for $12-48 \mathrm{~h}$. The caspase -3 and caspase- 9 activities of the cells were determined before the extract treatment and used as control. Different letters $(a-d)$ denote significant difference among groups $(p<0.05)$. Each value represents mean \pm S.D. $(n=3)$. 


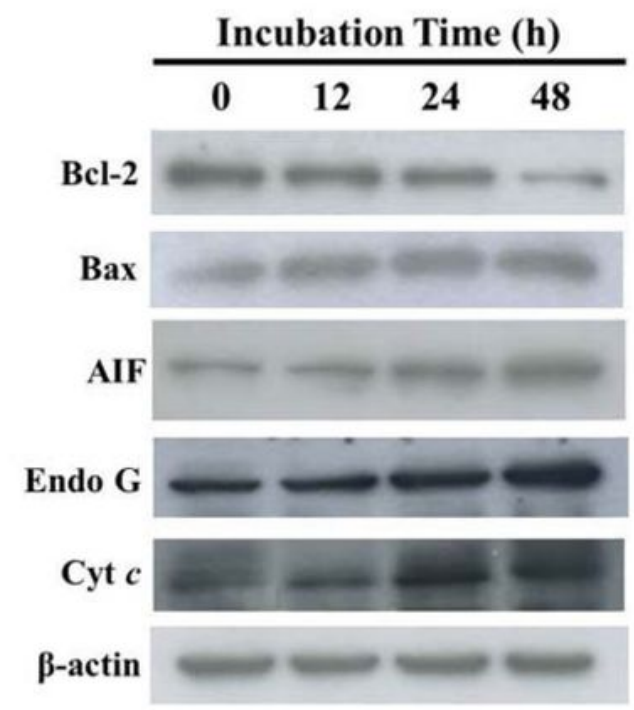

B
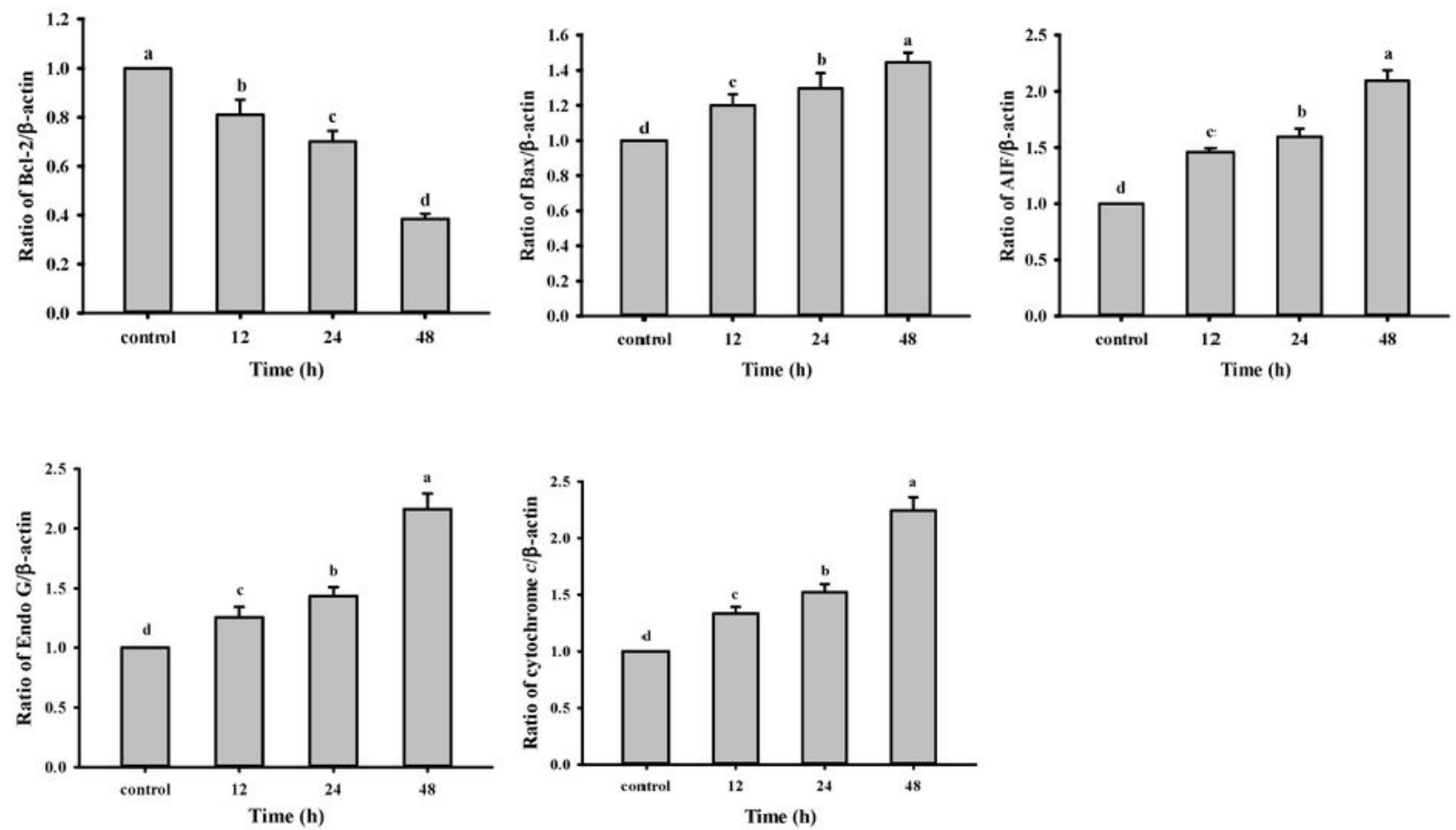

Figure 6

Effect of ethyl acetate fraction extract (EAFE) on the protein expression of Bcl-2, Bax, AlF, Endo G, and cytochrome c in HepG2 cells treated with $350 \mu \mathrm{g} / \mathrm{mL}$ of EAFE for 12-48 h. The Bcl-2, Bax, AlF, Endo G, and cytochrome $\mathrm{c}$, expression levels of the cells were determined before the extract treatment and used as control. Different letters $(a-d)$ denote significant difference among groups $(p<0.05)$. Each value represents mean \pm S.D. $(n=3)$. 
A

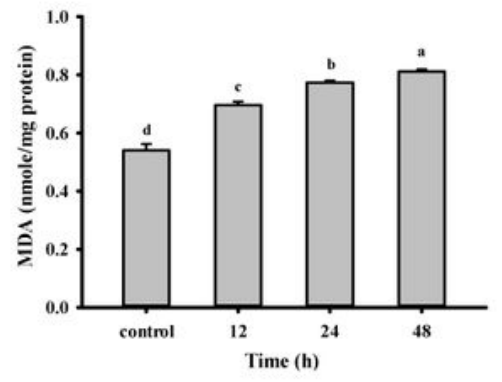

C

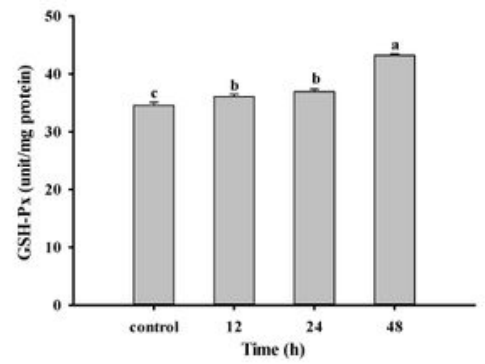

$\mathbf{E}$

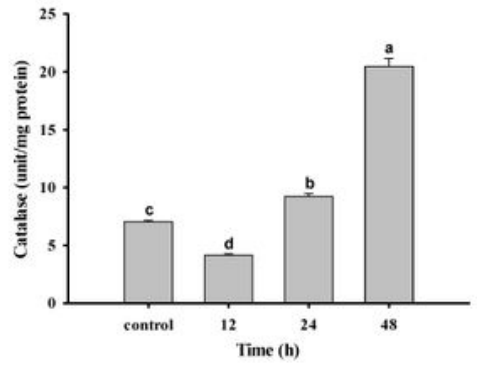

B

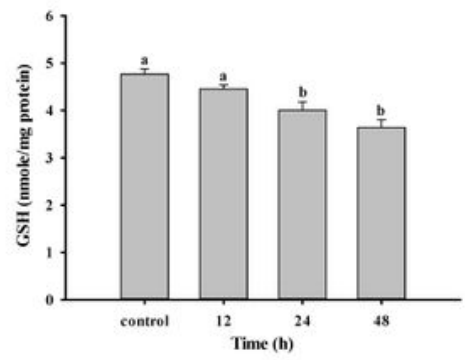

D

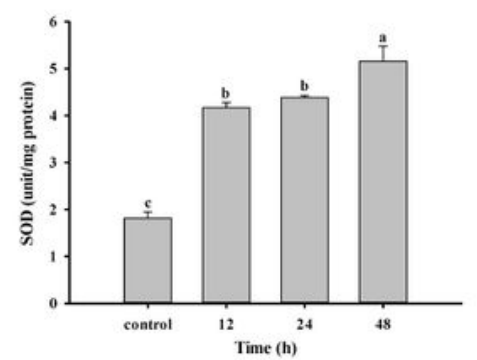

\section{Figure 7}

Effect of ethyl acetate fraction extract (EAFE) on MDA levels (A), GSH levels (B), GSH-Px activity (C), SOD activity (D), and catalase activity (E) of HepG2 cells treated with $350 \mu \mathrm{g} / \mathrm{mL}$ of EAFE for $12-48 \mathrm{~h}$. The data are the mean \pm S.D. $(n=3)$. Different letters $(a-d)$ denote significant differences between groups $(P$ $<0.05)$. 


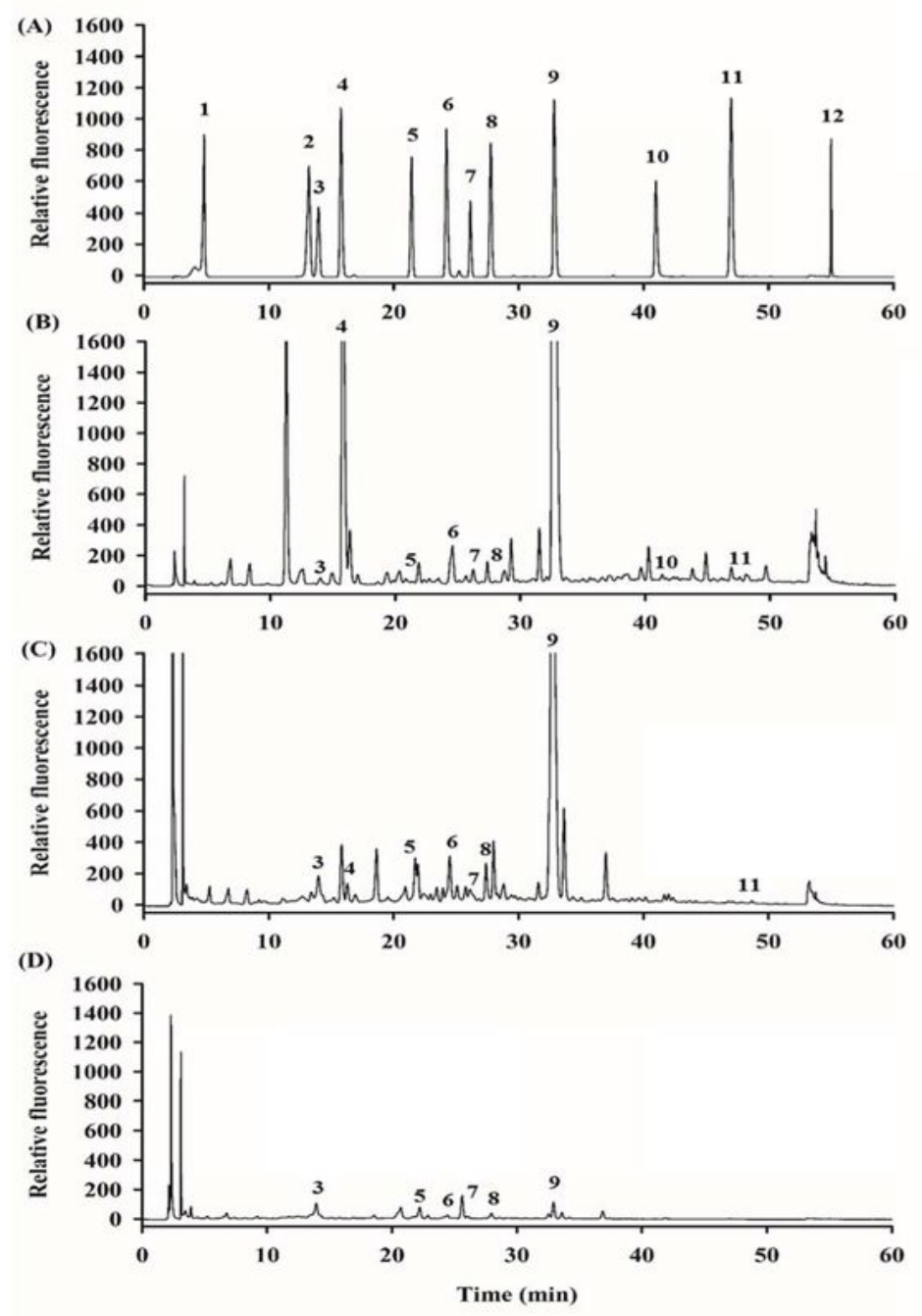

\section{Figure 8}

The polyphenolic profiles of (A) standards, (B) EAFE (25 mg/mL), (C) NBFE (25 mg/mL), and (D) WFE (25 $\mathrm{mg} / \mathrm{mL}$ ) from $\mathrm{G}$. hederacea L.. 1, gallic acid (4.83 min); 2, catechin (13.3 min); 3, chlorogenic acid (13.97min); 4, caffeic acid (15.90 min); 5, daidzin (21.29 min); 6, ferulic acid (24.11 min); 7, rutin (26.00 min); 8, genistin (27.95 min); 9, rosmarinic acid (32.92 min); 10, quercetin (40.71 min); 11, genistein (46.87 min); 12, flavone (55.12 $\mathrm{min})$. 


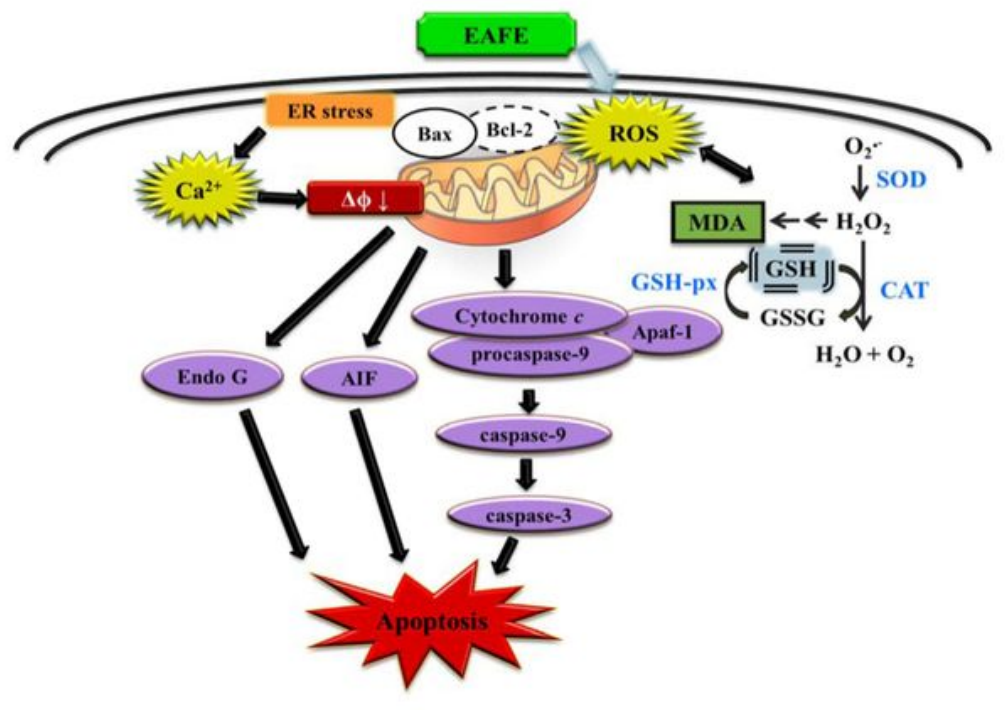

Figure 9

A proposed model illustrates the molecular mechanism and the overall possible signaling pathways of ethyl acetate fraction extract (EAFE)-induced apoptosis in HepG2 cells.

\section{Supplementary Files}


This is a list of supplementary files associated with this preprint. Click to download.

- HWGEAHepG2cellsgraphicalabstractCM.jpg 